\title{
Environmental Sustainability of Open-Pit Coal Mining Practices at Baganuur, Mongolia
}

\author{
Jonghoon Park ${ }^{1}{ }^{\circledR}$, Eunhye Kwon ${ }^{1}$, Euijin Chung ${ }^{1}$, Ha Kim ${ }^{1}$, Batbold Battogtokh ${ }^{2}$ and \\ Nam C. Woo ${ }^{1, *(D)}$ \\ 1 Department of Earth System Sciences, Yonsei University, Seoul 03722, Korea; pjhwhdgns@yonsei.ac.kr (J.P.); \\ oyn0824@yonsei.ac.kr (E.K.); sapari93@hanmail.net (E.C.); kimha8965@yonsei.ac.kr (H.K.) \\ 2 Department of Mining, Mongolian University of Science and Technology, Ulaanbaatar 14191, Mongolia; \\ bbold@must.edu.mn \\ * Correspondence: ncwoo@yonsei.ac.kr; Tel.: +82-2-2123-2674
}

Received: 20 November 2019; Accepted: 23 December 2019; Published: 27 December 2019

\begin{abstract}
In this paper, we studied one of the largest coal mines in Mongolia, the Baganuur Coal Mine, in terms of environmental sustainability related to mining practices, with a focus on discharged water and waste sediments. The present quality and potential for future pollution were assessed. Based on World Health Organization and Mongolian guidelines, groundwater pumped from the mining operations could be used for drinking and domestic purposes. In addition, based on the Na absorption ratio, groundwater samples from GW-2 and GW-3 could be used as agriculture water supplies with salinity reduction, or used to grow halophytes as a measure for desertification control and pasture production. All waste soil samples appeared to have a desertification potential. Dust particles smaller than $150 \mu \mathrm{m}$ comprised more than $80 \%$ of soil samples, which had arsenic levels higher than the Mongolian soil pollution standards. In addition, soil collected between coal seams (S-5) showed high sulphur content based on X-ray fluorescence (XRF) and scanning electron microscopy-energy dispersive X-ray (SEM-EDX) spectroscopy analyses, strong potential for producing acid mine drainage in the analysis of $\mathrm{pH}$ of net acid generation and net acid production potential, and potential for leaching of metals, such as Co. Therefore, the Baganuur Coal Mine requires soil pollution control measures to mitigate the risks of dust and desertification. In this perspective, mine groundwater could be used to reduce environmental stresses by supporting pasture crops such as halophytes on waste disposal sites, thereby preventing dust issues and desertification. Continuous efforts, including monitoring and enacting environmental management measures, are needed from both the mining company and the government to ensure sustainable mine development.
\end{abstract}

Keywords: Baganuur coal mine; environmental sustainability; soil pollution; water quality

\section{Introduction}

Development and the subsequent increase in standard of living worldwide have resulted in elevated demands for raw materials and ores [1]. Thus, greater exploitation of natural resources through mining is needed. In terms of natural mineral resources, Mongolia is one of the richest countries in the world, and mining is the country's main industry, accounting for $60 \%$ of its gross industrial output [2]. However, mining processes can cause various environmental problems, including deforestation, soil erosion, destruction of the natural landscape, landslides, water-level reduction and surface water depletion through dewatering, as well as water and soil pollution from mining waste and tailing dust [3-7].

Through natural weathering processes driven by rain and wind, waste rocks and overburden can be direct sources of pollution [8,9]. Acid mine drainage (AMD) occurs when pyrite and sulphide 
minerals make contact with water and oxygen in the air, producing acid $\left(\left[\mathrm{H}^{+}\right]\right)$through the following reaction [10-13]:

$$
4 \mathrm{FeS}_{2}(\text { Pyrite })+15 \mathrm{O}_{2}+14 \mathrm{H}_{2} \mathrm{O} \rightarrow 4 \mathrm{Fe}(\mathrm{OH})_{3}+8 \mathrm{SO}_{4}{ }^{2-}+16 \mathrm{H}^{+}
$$

These acids act as solutes, causing leaching of metals from the waste and increasing the potential for subsequent water and soil contamination through dissolution and precipitation processes of secondary minerals [12-16]. Therefore, environmental management systems must be implemented to prevent and mitigate various environmental issues and improve the sustainability of both the mining industry and the communities living in mining areas.

Two types of mining techniques are used: Open-pit mining and underground mining. Open-pit mining includes blasting of soil and vegetation to access underground ore layers or coal seams [17]. Consequently, this method produces large volumes of mining waste, including soil and overburden, which increase the vulnerability of mining environments to soil erosion and pollution. The Baganuur Coal Mine was first excavated as an open-pit mine in 1978. It is one of the largest coal mines in Mongolia, covering about $60 \mathrm{~km}^{2}$, and supplies mostly to the power plants in Ulaanbaatar, the capital city of Mongolia. The Baganuur Coal Mine Expansion Feasibility Study [18] reported that, based on the amount of coal mined to date (over $100 \mathrm{Mt}$ ) and the amount of identified reserves as of $2015(812 \mathrm{Mt})$ mining can continue for at least several decades.

Over the 40 years since 1978, the amounts of waste soil and groundwater pumping rate were $337 \mathrm{Mbcm}$ and $1100 \mathrm{~m}^{3} / \mathrm{h}$, respectively. Of the discharged water, $49 \%$ is supplied to the local power plant, $21 \%$ to a nearby lake and $30 \%$ onto fields. Considering the continuing exploitation of coal in the mine, the amounts of waste soil and groundwater pumping generated will be enormous, and could be limiting factors for the sustainable development of the mine due to environmental degradation in the surrounding area. Therefore, it is important to understand the present status of the impact on the environment to plan for sustainable development in the future. The objectives of the present study were to assess the pollution potential of the water and soil environment based on field data and to provide options for sustainable development of the Baganuur Coal Mine and nearby areas.

\section{Materials and Methods}

\subsection{Study Area}

Baganuur ( $\left.\mathrm{N} 47^{\circ} 43^{\prime} 12.5^{\prime \prime} \mathrm{E} 108^{\circ} 18^{\prime} 51.1^{\prime \prime}\right)$ is located about $130 \mathrm{~km}$ east of Ulaanbaatar, at an elevation of 1333-1376 m above sea level (www.baganuurmine.mn). It has a cold, dry climate with an annual mean precipitation of $288 \mathrm{~mm}$ and extreme temperatures in summer and winter of -24.2 and $16.5^{\circ} \mathrm{C}$ (Figure 1). The topography of the area is characterised by wide valleys, which are bounded by small hilly mountains to the west and east. The main river system is the Kherlen River, flowing north to south (inset, Figure 1).

Geologically, the Baganuur Coal Basin is part of the larger Choir Nyalga Coal Basin, which is a rift-type basin with fluvial-swamp, fluvial-lacustrine, deltaic-fluvial, and fluvial sediments. The direction of the basin axis is southwest-northeast. The Baganuur Basin is filled with Jurassic and Cretaceous sediments overlain with Quaternary alluvial, deluvial, and aeolian sediments [19]. The Khukhteeg formation consists of conglomerate, gravel, sand, silt, and brown coal with an average thickness of $450 \mathrm{~m}$. Three major coal seams are exposed within the Cretaceous clastic sedimentary layers, which have a synclinal structure in the north-northeast-south-southwest direction. The width and length of these layers are 3 and $8 \mathrm{~km}$, respectively, and their thickness ranges from 4 to $25 \mathrm{~m}$, with an average of $15 \mathrm{~m}$ [20]. A Quaternary sand and gravel layer of $6 \mathrm{~m}$ thickness covers the clastic sedimentary rock. Regional groundwater flows from the Khentii Mountains in the northwest toward the southeast across the mining area (www.baganuurmine.mn).

The mine site consists of mining pits, offices, and associated infrastructure. The mine is dewatered with advance dewatering bores supported by in-pit sump pumping. The dewatering product is piped 
away from the mine site to the Baganuur thermal plant and local surface waterways. The mine's portable water supply is provided by the public water supply bores of Baganuur Water LLC. Wastewater discharge is piped to the district wastewater treatment plant.

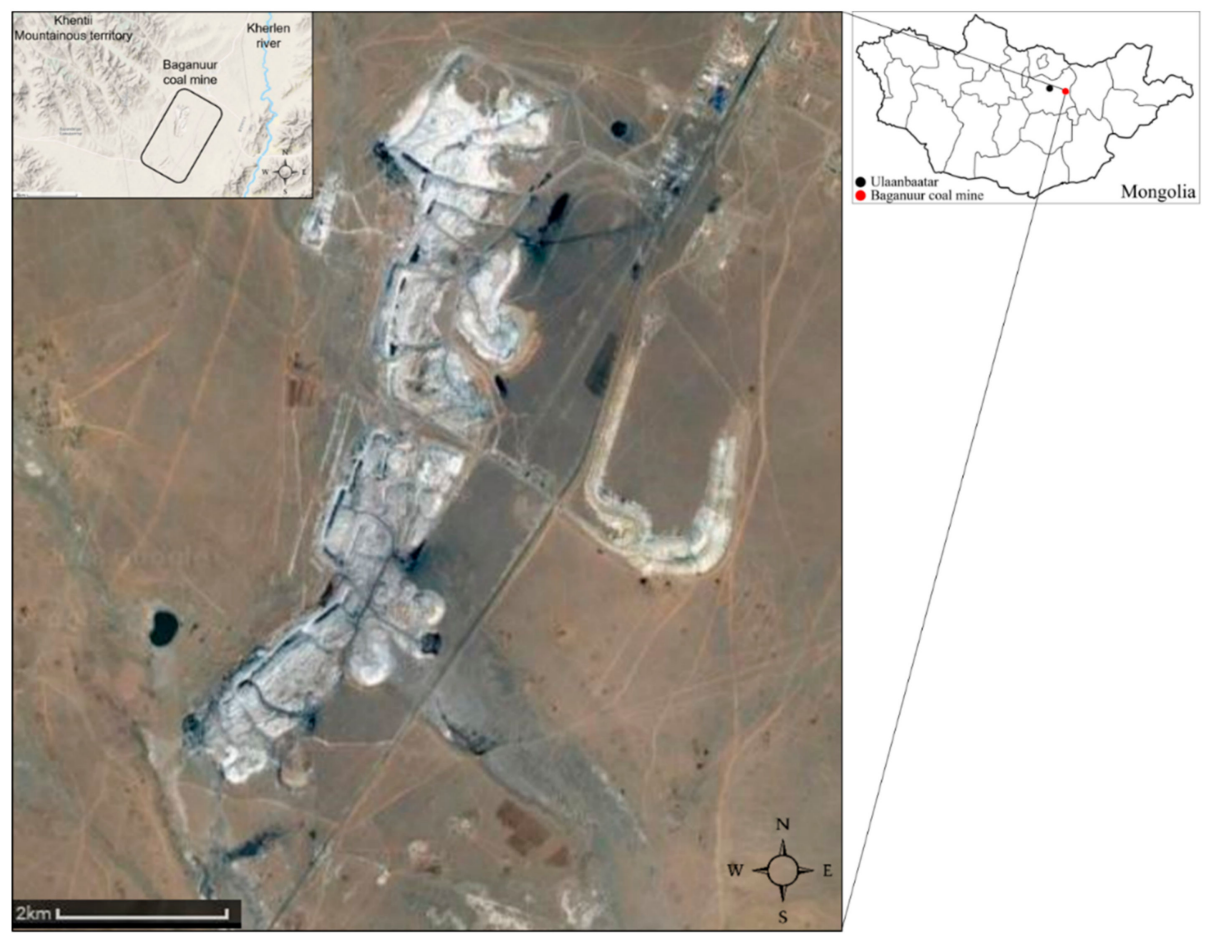

Figure 1. Location of the Baganuur Coal Mine in Mongolia (photos adapted from Google).

\subsection{Sampling and Field Study}

Geochemical information of water and soil in the mining area would be useful for understanding the waste characteristics of inorganic contaminants and the generation of acid mine drainage [21]. The field survey and sampling campaigns were carried out in October 2017 and May 2018 by teams from Yonsei University (Seoul, Korea), and Mongolian University of Science and Technology (Ulaanbaatar, Mongolia). Since the Baganuur Coal Mine is in operation, water and soil sampling were performed with the guidance and cooperation of mine staff.

Water samples were collected from ten points, including groundwater from the dewatering system (GW-1, -2, -3, -4, and -5), discharged water (DW-1 and -2), the collection station (CS), lake, and sump water (SW) (Table A1, available in Appendix A). The depths of the dewatering wells were 180 (GW-1), 226 (GW-2), 270 (GW-3), 240 (GW-4), and $260 \mathrm{~m}$ (GW-5). Water samples were filtered through $0.45 \mu \mathrm{m}$ membrane filters and then preserved for laboratory analysis of cations and anions in polypropylene bottles. Samples for cation and metal analysis were preserved by the addition of concentrated nitric acid to a lower solution $\mathrm{pH}$ below 2 , and those for the anion analysis were refrigerated after filtration [22,23]. On site, water samples were measured for electrical conductivity $(\mathrm{EC} ; \mu \mathrm{S} / \mathrm{cm})$, dissolved oxygen content $(\mathrm{mg} / \mathrm{L})$, oxidation-reduction potential $(\mathrm{mV}), \mathrm{pH}$, and temperature using a portable multi-probe (Orion Star A329; Thermo Scientific). Alkalinity was measured using the acid titration method.

Five soil samples were collected, including waste soil (S-1 and -2), background soil (S-3), soil collected near the sump water (S-4), and soil collected between coal seams (S-5) (Table A1). For sampling, the top soil layer of about $10 \mathrm{~cm}$ was removed in $2 \times 2 \mathrm{~m}^{2}$ area, and then soil samples were obtained by mixing soils from the next $15 \mathrm{~cm}$ of depth collected at five points in plastic bags [24]. Soil samples represent the areas of approximately $300 \times 300 \mathrm{~m}^{2}(\mathrm{~S}-1), 300 \times 1000 \mathrm{~m}^{2}(\mathrm{~S}-2), 100 \times 200 \mathrm{~m}^{2}$ (S-4), and $100 \times 200 \mathrm{~m}^{2}(\mathrm{~S}-5)$, respectively, in the study area. 


\subsection{Laboratory Analysis}

In the water samples, cations $(\mathrm{Na}, \mathrm{K}, \mathrm{Ca}, \mathrm{Mg}, \mathrm{Fe}, \mathrm{Mn}, \mathrm{Si}, \mathrm{Al}, \mathrm{As}, \mathrm{Cr}, \mathrm{Co}, \mathrm{Cu}, \mathrm{Mo}, \mathrm{Ni}, \mathrm{Rb}, \mathrm{Sr}, \mathrm{V}, \mathrm{Zn}$, $\mathrm{Li}, \mathrm{B}, \mathrm{Pb}, \mathrm{Ag}$, and $\mathrm{Cd})$ and anions $\left(\mathrm{Cl}, \mathrm{SO}_{4}, \mathrm{NO}_{3}, \mathrm{Br}\right.$, and $\left.\mathrm{F}\right)$ were analysed using inductively coupled plasma-optical emission spectrometry (ICP-OES; iCAP 7000; Thermo Scientific, Waltham, MA, USA) and ion chromatography (IC; 883 Basic IC plus, Metrohm, Herisau, Switzerland), respectively, at the groundwater laboratory of Yonsei University. The analytical results were checked for electrical neutrality, and results with charge balance errors of less than $10 \%$ were used for further interpretation [25]. Data analysis was conducted using the Aquachem program version 2014.2 (Waterloo Hydrogeologic, Waterloo, ON, Canada) for chemical plots and SPSS version 24 (IBM Corp., Armonk, NY, USA) for statistical analysis.

Soil samples were analysed after drying. Particles less than $2 \mathrm{~mm}$ in diameter were analysed with a laser-based particle size analyser (Mastersizer 2000; Malvern Instruments, Malvern, UK). To elucidate their mineral and chemical compositions, they were also ground and analysed using $\mathrm{X}$-ray fluorescence (XRF; PW2404; PHILIPS, Amsterdam, The Netherlands), X-ray diffraction (XRD; Miniplex II, Rigaku, Tokyo, Japan), and scanning electron microscopy (JSM-5610LV; JEOL, Tokyo, Japan) with energy dispersive X-ray spectroscopy (Oxford Instruments, Abingdon, UK) (SEM-EDX) at Yonsei University. To assess the environmental risk from mine dust, the heavy metal contents of dust-sized particles from soil samples were acid digested and analysed using ICP-OES following standard methods [26,27].

Potential of samples to leach metals from rocks and soils in mining wastes were evaluated through leaching tests following the ASTM D4793-09 method (Standard Test Method for Sequential Batch Extraction of Waste with Water). This method requires mixing $50 \mathrm{~g}$ of dry soil with $1 \mathrm{~L}$ of distilled water for $18 \mathrm{~h}$ and then filtering the mixture through a $0.45 \mu \mathrm{m}$ membrane filter. The remaining slurry is mixed with a further $1 \mathrm{~L}$ of distilled water; this filtering procedure was carried out four times. The filtrates were analysed using ICP-OES and IC for cations and anions, respectively [28,29].

Recent studies have suggested that changes in the particle size distribution (PSD) provide useful indicators of soils that require management or are subject to erosion or desertification [30]. Thus, to assess the desertification potential of this site, the fractal dimension $\left(\mathrm{D}_{\mathrm{m}}\right)$ of PSD was calculated as follows [31]:

$$
\frac{\mathrm{V}\left(\mathrm{r}<\mathrm{R}_{\mathrm{i}}\right)}{\mathrm{V}_{\mathrm{T}}}=\left(\frac{\mathrm{R}_{\mathrm{i}}}{\mathrm{R}_{\max }}\right)^{3-\mathrm{D}_{\mathrm{m}}}
$$

where $r$ is the particle size, $R_{i}$ is the particle size for grade $i$ in the particle size grading, $V\left(r<R_{i}\right)$ is the volume of soil particles of diameter less than $R_{i}, V_{T}$ is the total volume of soil particles, and $R_{\max }$ is the maximum diameter of soil particles.

The soil particle content was sorted by particle size at various soil levels and a diagram was plotted using $\log \left(\frac{\mathrm{V}\left(\mathrm{r}<\mathrm{R}_{\mathrm{i}}\right)}{\mathrm{V}_{\mathrm{T}}}\right)$ as the ordinate, $\log \left(\frac{\mathrm{R}_{\mathrm{i}}}{\mathrm{R}_{\max }}\right)$ as the abscissa. Then, a linear fit to the data was estimated with the slope of $3 D_{m}$. Subsequently, the fractal dimension $\left(D_{m}\right)$ becomes 3 slope [31,32].

\section{Results and Discussion}

\subsection{Hydrogeochemical Characteristics of Water}

Water samples from the Baganuur Coal Mine had a pH of 6.63-9.02 and EC of 535-1703 $\mu \mathrm{S} / \mathrm{cm}$ (Table A2). Based on their total dissolved solids (TDS) contents, GW-2, -3, -4, -5, DW-2, lake, and SW were freshwater (TDS $<1000 \mathrm{mg} / \mathrm{L}$ ), while GW-1 and DW-1 were brackish, with relatively high TDS of $1145-1703 \mathrm{mg} / \mathrm{L}$ [33]. Spatiotemporal variations in basic water chemistry were evaluated using the Stiff diagram method (Figure 2). Water samples showed two dominant types: $\mathrm{Na}-\mathrm{HCO}_{3}$ and $\mathrm{Ca}-\mathrm{HCO}_{3}$. One sample, GW-4, showed a change in water types, from $\mathrm{Na}-\mathrm{HCO}_{3}$ in October to Ca- $\mathrm{HCO}_{3}$ in May. Changes in major water composition could be derived from various reasons such as changes of hydrochemical reactions following flow-path changes due to mining stages, implying that long-term monitoring is warranted. 

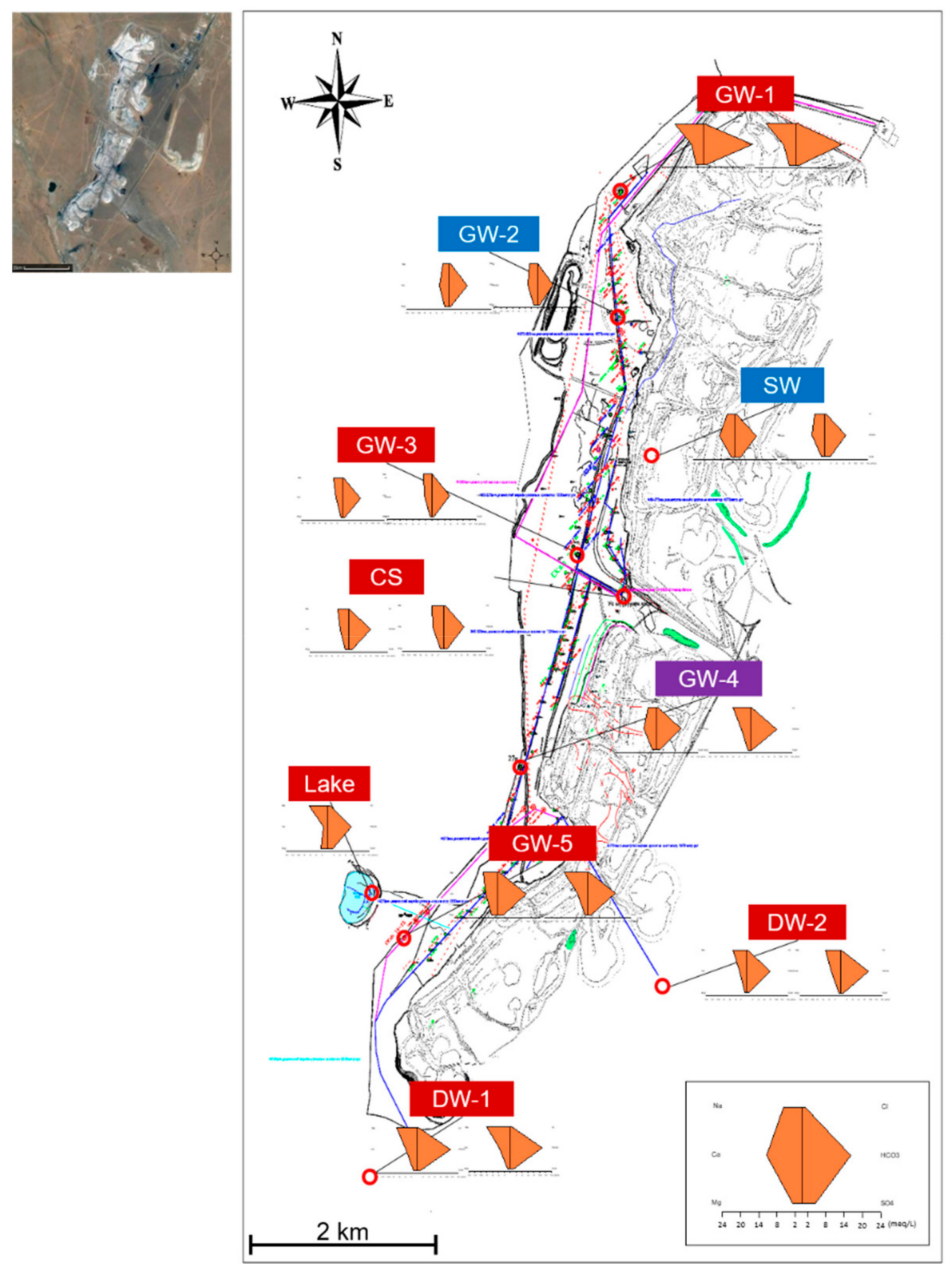

Figure 2. Stiff diagrams of water samples collected in October 2017 (left) and May 2018 (right). Sample numbers in red and blue boxes indicate $\mathrm{Na}-\mathrm{HCO}_{3}$-type and $\mathrm{Ca}-\mathrm{HCO}_{3}$-type water, respectively. The purple box indicates a sample that changed type over time.

Hydrogeochemical processes were deduced based on the composition of 2017 and 2018 water samples using statistical methods, including factor analysis and Pearson correlation analysis. All water samples had $\mathrm{Na} / \mathrm{Cl}$ and $\mathrm{HCO}_{3} / \mathrm{SiO}_{2}$ ratios greater than 1 and 10, respectively. In addition, except for the lake sample, the samples had $\mathrm{Ca} / \mathrm{SO}_{4}$ ratios exceeding 0.5 (Table A3). These results indicate that carbonate dissolution has a stronger impact on water composition than silicate weathering.

Factor analysis showed that 70\% (October 2017) or 75\% (May 2018) of sample variation was affected by two major factors (Table A4). The first factor was associated with $\mathrm{Na}, \mathrm{K}, \mathrm{Ca}$, and $\mathrm{Mg}$ among cations and $\mathrm{HCO}_{3}$ among anions, explaining $44 \%$ and $46 \%$ of the compositional variance in 2017 and 2018, respectively. Considering the natural environment of the mine formed in the lake depositional environment in the dry climate, the dominant weathering process generated these compositions appeared to be the dissolution of carbonate minerals such as calcite, dolomite, trona $\left(\mathrm{NaHCO}_{3} \cdot \mathrm{Na}_{2} \mathrm{CO}_{3}\right)$, natron $\left(\mathrm{Na}_{2} \mathrm{CO}_{3} \cdot 10 \mathrm{H}_{2} \mathrm{O}\right)$, and nahcolite $\left(\mathrm{NaHCO}_{3}\right)[25,34]$. The second factor was related to $\mathrm{SO}_{4}$ and $\mathrm{NO}_{3}$, and explained $25 \%$ and $29 \%$ of sample variance in 2017 and 2018, respectively. $\mathrm{SO}_{4}$ and $\mathrm{NO}_{3}$ showed positive correlations with $\mathrm{Ca}$ (Tables $\mathrm{A} 5$ and A6). Therefore, the source of $\mathrm{SO}_{4}$ could be attributed to dissolution of sulphate minerals such as anhydrite $\left(\mathrm{CaSO}_{4}\right)$ and gypsum $\left(\mathrm{CaSO}_{4} \cdot 2 \mathrm{H}_{2} \mathrm{O}\right)$ and that of $\mathrm{NO}_{3}$ to a compound used in mining explosives, $\mathrm{Ca}\left(\mathrm{NO}_{3}\right)_{2}$ [35]. In summary, the chemical composition of water at the Baganuur Coal Mine appeared to be driven primarily by the dissolution of carbonate and sulphate, with a secondary influence of explosive residue. 


\subsection{Water Quality and Pollution Potential}

In Mongolia, surface water does not provide sufficient water supply because of climate conditions. For residents of the Baganuur area, groundwater is the principal source of water, and water is also pumped from the nearby Kherlen River, located $13 \mathrm{~km}$ east of the mining area. Considering the continuous water level decline occurring due to dewatering during the mining process, recycling of water removed from the mine could benefit the local residents through reduction of the groundwater pumping cost, lessening of the potential for land subsidence and preserving valuable water resources for sustainable management of the local environment [4,5].

Compared with the Mongolian water pollution standard [36] and World Health Organization (WHO) drinking water guidelines [37] (Table A7), all samples had concentrations of water quality parameters below the WHO guideline levels. However, some components, such as Fe, exceeded Mongolian standards in GW-1, $-2,-3,-4,-5$, and CS. Discharged lake water had $\mathrm{pH}$ and $\mathrm{K}$ levels above the Mongolian standard. Na and K also exceeded the standard in SW and GW-1, respectively. DW-1 and -2 , representing about $30 \%$ of the total dewatering water, met the WHO and Mongolian quality standards. Thus, water from these wells could be used as a drinking and domestic water resource while supporting mine operations.

\subsection{Salinity Hazard}

In arid and semi-arid areas, the salinity and sodicity of water can inhibit the growth of crops and other plants [38]. To evaluate the potential effects of recycling water from mining for agricultural usage, the salinity and Na hazards were estimated using the Na adsorption ratio (SAR) and EC (Figure 3). The SAR reflects the ratio of cation exchange processes involving $\mathrm{Na}$ in water to those of $\mathrm{Ca}$ and $\mathrm{Mg}$ in soil, and is calculated as:

$$
S A R=\frac{N a}{\sqrt{\frac{C a+M g}{2}}}
$$

where ionic concentrations are in units of meq/L $[39,40]$.



Figure 3. Wilcox diagram for the classification of irrigation waters (GW: Groundwater; DW: Discharge water; CS: Collection station; SW: Sump water). 
From the Wilcox plot displayed in Figure 3, the water samples showed medium to high salinity hazard and low Na hazard. GW-1 water shows high salinity and medium Na hazard, while GW-2 and -3 had medium salinity and low Na hazards. Other water samples show high salinity and low Na hazards. Thus, if salinity can be reduced, the mine water could safely be used for local agriculture. If not, the water could be used to grow halophytes for animal fodder, as reported by Le Houérou et al. [41] and El Shaer et al. [42], to prevent desertification and reclaim the area of overburden deposition from the open-pit mine [43]. The agriculture and stock-farming industries in Mongolia account for $12 \%$ of the gross domestic product, with pastures accounting for $98 \%$ of cropland and $75 \%$ of the country's total area [2]. Therefore, if its wastewater can be used to support pastures and the growth of halophytes, the mining process could contribute to sustainable management of the local environment.

\subsection{Acid Generation Potential}

AMD is a common issue in mining areas that can cause dissolution of metal components from waste soils and sediments, leading to secondary contamination due to precipitation of common $\mathrm{Fe}$ oxyhydroxides along waterways [14,44]. Thus, the AMD potential of soil samples was assessed through analysis of $\mathrm{pH}, \mathrm{XRD}, \mathrm{XRF}$, and SEM-EDX results.

The main components of the sampled soils were quartz, microcline and albite, and no sulphide minerals that could cause AMD were identified in XRD analysis. However, soil sample S-5, which was collected between the coal seams (Figure 4), was acidic (pH: 2.77) (Table 1). S-5 had a sulphur content of $0.37 \%$ based on XRF analysis, higher than other soils, as well as a sulphur level of $0.58 \%$ based on SEM-EDX analysis, which was not detected in other samples (Table 2). The low pH of S-5 could be attributed to acid-generating reactions of its sulphur components [9,45-48].

The acid generation potential of sample S- 5 was quantified to evaluate the AMD potential using plots of $\mathrm{pH}$ of net acid generation $\left(\mathrm{NAG}_{\mathrm{pH}}\right)$ versus net acid production potential (NAPP). The average $\mathrm{NAG}_{\mathrm{pH}}$ was 2.98 (2.97-3.00) and the average NAPP was $8.67 \mathrm{~kg} \mathrm{H}_{2} \mathrm{SO}_{4} /$ ton (8.08-9.30 $\mathrm{kg} \mathrm{H}_{2} \mathrm{SO}_{4} /$ ton). An $\mathrm{NAG}_{\mathrm{pH}}$ value below 4.5 with significant NAPP indicates that a sample has sufficient acid generation potential for the AMD process (Figure A3) $[47,48]$.

Table 1. $\mathrm{pH}$ and $\mathrm{XRF}$ results of soil samples.

\begin{tabular}{|c|c|c|c|c|c|c|c|c|c|c|c|c|c|c|c|c|c|c|c|}
\hline \multirow{2}{*}{ Sample } & \multirow{2}{*}{$\mathrm{pH}$} & \multicolumn{18}{|c|}{ Weight (\%) } \\
\hline & & Si & Al & $\mathrm{Fe}$ & $\mathbf{K}$ & $\mathrm{Ca}$ & $\mathrm{Na}$ & $\mathrm{Ti}$ & $\mathrm{Mg}$ & $\mathbf{P}$ & Mn & $S$ & $\mathrm{Zr}$ & $\mathrm{Cr}$ & $\mathbf{R b}$ & $\mathrm{Zn}$ & $\mathrm{Sr}$ & $\mathrm{Cu}$ & $\mathrm{Au}$ \\
\hline S-1 & 7.10 & 67.7 & 12.4 & 7.49 & 7.38 & 1.77 & 1.04 & 1.02 & 0.48 & 0.17 & 0.12 & 0.09 & 0.08 & 0.07 & 0.06 & 0.05 & 0.04 & ND & ND \\
\hline $\mathrm{S}-2$ & 6.17 & 70.1 & 11.7 & 5.73 & 8.39 & 1.16 & 0.81 & 1.03 & 0.41 & 0.18 & 0.13 & 0.04 & 0.08 & ND & 0.05 & 0.04 & 0.04 & 0.09 & ND \\
\hline S-3 & 6.44 & 69.1 & 11.7 & 6.10 & 6.33 & 2.75 & 2.01 & 0.97 & 0.45 & 0.13 & 0.18 & ND & 0.09 & 0.06 & 0.05 & 0.03 & 0.09 & ND & ND \\
\hline S-4 & 7.50 & 65.5 & 13.5 & 8.38 & 6.90 & 2.00 & 1.07 & 1.01 & 0.77 & 0.19 & 0.15 & 0.14 & 0.09 & 0.07 & 0.06 & 0.03 & 0.05 & 0.06 & 0.04 \\
\hline S-5 & 2.77 & 71.9 & 11.7 & 4.59 & 7.99 & 1.07 & 1.10 & 0.63 & 0.32 & 0.09 & 0.08 & 0.37 & 0.06 & ND & 0.04 & ND & 0.04 & ND & ND \\
\hline
\end{tabular}

Table 2. SEM-EDX results of soil samples.

\begin{tabular}{cccccccccccccc}
\hline \multirow{2}{*}{ Sample } & \multicolumn{10}{c}{ Weight (\%) } \\
\cline { 2 - 13 } & $\mathbf{O}$ & $\mathbf{S i}$ & $\mathbf{A l}$ & $\mathbf{F e}$ & $\mathbf{M g}$ & $\mathbf{C a}$ & $\mathbf{K}$ & $\mathbf{N a}$ & $\mathbf{T i}$ & $\mathbf{S}$ & $\mathbf{C u}$ & $\mathbf{Z n}$ & $\mathbf{B}$ \\
\hline S-1 & 48.38 & 32.64 & 8.80 & 3.93 & 0.47 & 0.69 & 3.07 & 1.01 & 1.02 & ND & ND & ND & ND \\
S-2 & 48.65 & 32.35 & 9.71 & 3.05 & 0.81 & 0.67 & 3.18 & 0.71 & 0.88 & ND & ND & ND & ND \\
S-3 & 47.71 & 32.42 & 7.97 & 4.91 & 0.86 & 1.04 & 3.32 & 1.76 & ND & ND & ND & ND & ND \\
S-4 & 62.58 & 8.96 & 3.35 & 1.42 & 0.31 & 0.27 & 0.70 & 0.26 & ND & ND & 0.37 & ND & 21.78 \\
S-5 & 48.34 & 31.96 & 9.11 & 3.41 & 0.39 & ND & 3.47 & 1.12 & 0.54 & 0.58 & ND & 1.09 & ND \\
\hline
\end{tabular}

ND indicates no detection. 


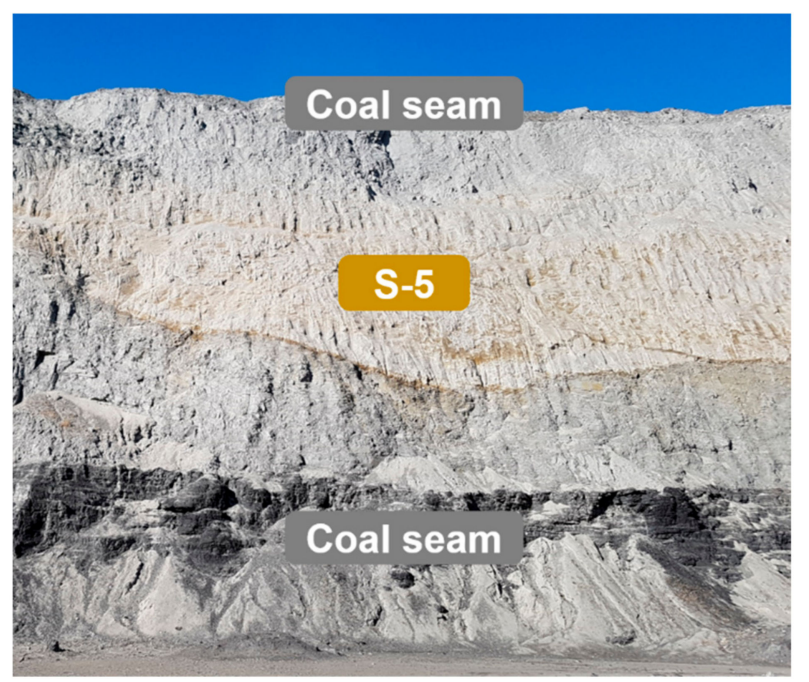

Figure 4. Soil sampling site between coal seams (S-5).

\subsection{Potential for Metal Leaching}

Metals in the mineral phase in waste sediments and soils can be dissolved in acidic water, such as AMD. When the solution's pH increases, dissolved metals can be re-precipitated in secondary mineral phases or sorbed onto solid surfaces, posing a risk as a potential source of water and soil pollution [14,44].

Soil samples were evaluated for the pollution potential due to leaching of metal contaminants through leaching tests following a standard method [29]. Figure 5 shows the results of soil $\mathrm{pH}$ changes over four consecutive leaching tests. The $\mathrm{pH}$ measurements of soil samples $\mathrm{S}-1,-2,-3$, and -4 (range: 5.63-7.19) were higher than that of distilled water blanks (range: 5.38-5.86), and the soil $\mathrm{pH}$ fell slightly during the tests. The $\mathrm{pH}$ of S-5 (range: 3.29-4.26) was much lower than those of other samples, and increased over repeated tests, indicating decreased levels of acid-generating materials.

From the leaching tests using $1 \mathrm{~kg}$ of soil, the total amount of $\mathrm{SO}_{4}$ in sample S-5 was $4019.07 \mathrm{mg} / \mathrm{kg}$, and those in S-1, $-2,-3$, and -4 were $34.03,210.95,3.27$, and $75.93 \mathrm{mg} / \mathrm{kg}$, respectively (Figure A4). The amount of $\mathrm{SO}_{4}$ leached and $\mathrm{pH}$ showed a negative correlation $(r=0.590$, significant at the $99 \%$ level), indicating that oxidation of sulphur in soils contributed to the low soil $\mathrm{pH}$.

Leaching tests detected $\mathrm{Ni}, \mathrm{Zn}$, and $\mathrm{Co}$, whereas $\mathrm{As}, \mathrm{Cd}, \mathrm{Cr}, \mathrm{Cu}, \mathrm{Pb}$, and $\mathrm{V}$ were below the detection limit of $0.2 \mathrm{mg} / \mathrm{kg}$ (Table 3). Mongolian soil pollution standards for Ni, Zn, and Co are 100, 150 , and $40 \mathrm{mg} / \mathrm{kg}$, respectively. All samples had Co concentrations in leachates exceeding the pollution standard. Notably, sample S-5 had a Co concentration of $803.12 \mathrm{mg} / \mathrm{kg}$, about 20 times the standard. Among the soils and waste sediments of the Baganuur mine, only sample S-5, collected between coal seams, showed pollution potential in terms of acid generation and subsequent leaching of Co into the water and soil environments; therefore, such soil requires appropriate preventive measures for sustainable development. 


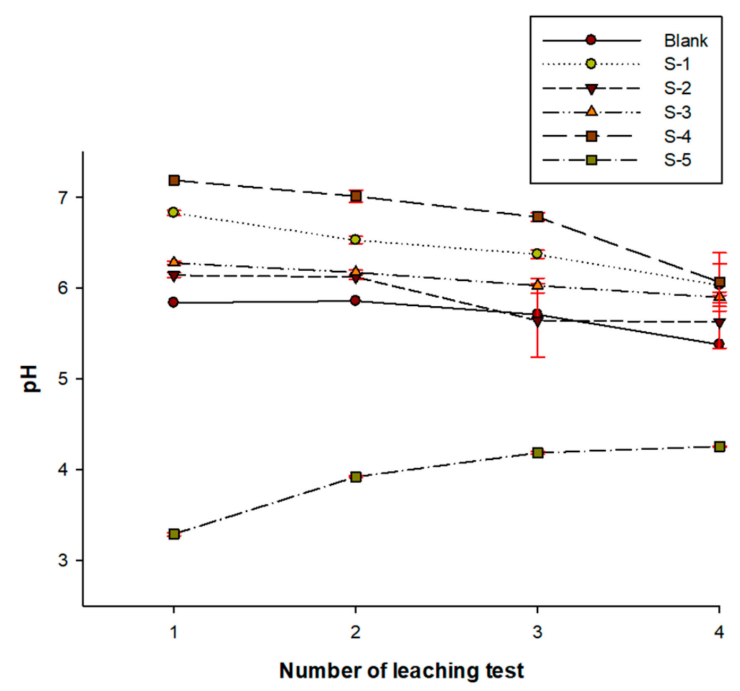

Figure 5. $\mathrm{pH}$ values from leaching tests of soil samples ( $\mathrm{x}$ axis: Total four times of leaching test sequential process, y axis: Hydrogen ion concentration).

Table 3. Leaching test results for $\mathrm{Ni}, \mathrm{Zn}$, and Co.

\begin{tabular}{cccc}
\hline \multirow{2}{*}{ Sample } & \multicolumn{3}{c}{ Total Concentration $\mathbf{( m g / \mathbf { k g } \pm \mathbf { s t d } . )}$} \\
\cline { 2 - 4 } & $\mathbf{N i}$ & $\mathbf{Z n}$ & Co \\
\hline Mongolian Soil pollution standards & 100 & 150 & 40 \\
S-1 & BDL & $1.29( \pm 0.218)$ & $54.61( \pm 2.146)$ \\
S-2 & BDL & $0.89( \pm 0.229)$ & $73.94( \pm 1.905)$ \\
S-3 & BDL & BDL & $54.77( \pm 1.032)$ \\
S-4 & BDL & $0.74( \pm 0.341)$ & $144.53( \pm 1.262)$ \\
S-5 & $1.10( \pm 0.002)$ & $5.74( \pm 0.066)$ & $803.12( \pm 27.760)$ \\
\hline
\end{tabular}

${ }^{*}$ BDL indicates below detection limit $(0.2 \mathrm{mg} / \mathrm{kg})$.

\subsection{Desertification Potential and Dust Generation}

The open-pit coal mining process can degrade forests and prairies thereby accelerating desertification in areas with dry climates such as Mongolia. The PSD, soil texture, and $\mathrm{D}_{\mathrm{m}}$ were evaluated (Table A8). The PSD showed that all soil samples consisted of more than $90 \%$ of fine materials, ranging from clay to fine sand. $D_{m}$ is a desertification indicator, where a low $D_{m}$ value indicates a higher desertification potential [32,49]. The $D_{m}$ values of the soil samples ranged from $1.951( \pm 0.053)$ to $2.288( \pm 0.040)$, lower than the extreme desertification value of $2.298( \pm 0.082)$ [49]. This result implies that mining in the Baganuur Coal Mine could have major impacts on the environment in terms of desertification.

Flying dust is generally described as particulate matter in the size range of 1-100 $\mu \mathrm{m}$ [50], and Sapko et al. [51] reported that the mean particle size in coal mining areas is about $150 \mu \mathrm{m}$. Human exposure to dust through the skin and inhalation can cause diseases such as pneumoconiosis, ischemic heart disease, and hard metal disease [50,52]. The PSD of soil samples of the Baganuur Coal Mine showed that more than $80 \%$ of the particles were smaller than $150 \mu \mathrm{m}$. Furthermore, As concentrations in the dust (range: $5.57-14.17 \mathrm{mg} / \mathrm{kg}$ ) exceeded the soil pollution standard in Mongolia of $4 \mathrm{mg} / \mathrm{kg}$ (Table 4). Since As is a carcinogen that can be absorbed into the body through skin exposure and inhalation [53,54], mine workers and residents living near the Baganuur Coal Mine are exposed to the risk of As poisoning. Consequently, measures should be implemented to prevent desertification and the generation of flying dusts for sustainable management of the mine. 
Table 4. Composition of heavy metals in dust and Mongolian soil pollution standards [55].

\begin{tabular}{|c|c|c|c|c|c|c|c|c|c|c|c|c|}
\hline \multirow{2}{*}{ Sample } & \multirow{2}{*}{$\begin{array}{c}\text { Below } 150 \\
\mu \mathrm{m}(\%)\end{array}$} & \multicolumn{11}{|c|}{$\mathrm{mg} / \mathrm{kg} \pm \mathrm{std}$} \\
\hline & & $\mathrm{Pb}$ & Cd & As & $\mathrm{Cr}$ & $\mathrm{Sr}$ & V & $\mathrm{Cu}$ & $\mathbf{N i}$ & Co & $\mathrm{Zn}$ & Mo \\
\hline $\begin{array}{l}\text { Mongolian soil } \\
\text { pollution standards }\end{array}$ & & 70 & 1.5 & 4 & 100 & 700 & 130 & 80 & 100 & 40 & 150 & 3 \\
\hline S-1 & 81.12 & $\begin{array}{c}7.78 \\
( \pm 0.0404)\end{array}$ & $\mathrm{BDL}$ & $\begin{array}{c}5.57 \\
( \pm 0.8549)\end{array}$ & $\begin{array}{c}17.31 \\
( \pm 2.7260)\end{array}$ & $\begin{array}{c}126.44 \\
( \pm 0.2 .6625)\end{array}$ & $\begin{array}{c}49.08 \\
( \pm 1.2806)\end{array}$ & $\begin{array}{c}31.01 \\
( \pm 1.0242)\end{array}$ & $\begin{array}{c}5.96 \\
( \pm 0.5925)\end{array}$ & $\begin{array}{c}15.76 \\
( \pm 0.4448)\end{array}$ & $\begin{array}{c}79.19 \\
( \pm 2.9052)\end{array}$ & BDL \\
\hline $\mathrm{S}-2$ & 100 & $\begin{array}{c}8.82 \\
( \pm 0.2377)\end{array}$ & BDL & $\begin{array}{c}8.34 \\
( \pm 0.7712)\end{array}$ & $\begin{array}{c}12.85 \\
( \pm 0.2536)\end{array}$ & $\begin{array}{c}112.90 \\
( \pm 0.3851)\end{array}$ & $\begin{array}{c}41.19 \\
( \pm 0.2778)\end{array}$ & $\begin{array}{c}23.94 \\
( \pm 0.2830)\end{array}$ & $\begin{array}{c}3.97 \\
( \pm 0.1614)\end{array}$ & $\begin{array}{c}12.44 \\
( \pm 0.3044)\end{array}$ & $\begin{array}{c}66.02 \\
( \pm 0.9377)\end{array}$ & $\mathrm{BDL}$ \\
\hline $\mathrm{S}-3$ & 94.75 & $\begin{array}{c}8.20 \\
( \pm 0.6163)\end{array}$ & BDL & $\begin{array}{c}14.17 \\
( \pm 1.3766)\end{array}$ & $\begin{array}{c}36.86 \\
( \pm 0.5023)\end{array}$ & $\begin{array}{c}216.74 \\
( \pm 9.6837)\end{array}$ & $\begin{array}{c}67.59 \\
( \pm 1.0617)\end{array}$ & $\begin{array}{c}35.77 \\
( \pm 1.0971)\end{array}$ & $\begin{array}{c}13.66 \\
( \pm 0.2380)\end{array}$ & $\begin{array}{c}17.40 \\
( \pm 0.2621)\end{array}$ & $\begin{array}{c}70.38 \\
( \pm 1.8438)\end{array}$ & BDL \\
\hline S-4 & 100 & $\begin{array}{c}7.96 \\
( \pm 0.8396)\end{array}$ & BDL & $\begin{array}{c}8.60 \\
( \pm 1.6423)\end{array}$ & $\begin{array}{c}18.30 \\
( \pm 0.6441)\end{array}$ & $\begin{array}{c}121.47 \\
( \pm 3.1256)\end{array}$ & $\begin{array}{c}50.65 \\
( \pm 0.4425)\end{array}$ & $\begin{array}{c}30.31 \\
( \pm 1.2879)\end{array}$ & $\begin{array}{c}5.95 \\
( \pm 0.2543)\end{array}$ & $\begin{array}{c}14.95 \\
( \pm 0.2383)\end{array}$ & $\begin{array}{c}80.56 \\
( \pm 0.7366)\end{array}$ & BDL \\
\hline S-5 & 85.98 & $\begin{array}{c}12.39 \\
( \pm 0.2861)\end{array}$ & BDL & $\begin{array}{c}11.16 \\
( \pm 0.8664)\end{array}$ & $\begin{array}{c}9.84 \\
( \pm 0.6902)\end{array}$ & $\begin{array}{c}134.22 \\
( \pm 6.1592)\end{array}$ & $\begin{array}{c}35.88 \\
( \pm 0.4203)\end{array}$ & $\begin{array}{c}17.95 \\
( \pm 0.6403)\end{array}$ & $\begin{array}{c}4.64 \\
( \pm 1.0600)\end{array}$ & $\begin{array}{c}13.72 \\
( \pm 0.2693)\end{array}$ & $\begin{array}{c}58.13 \\
( \pm 1.4714)\end{array}$ & BDL \\
\hline
\end{tabular}

BDL indicates below detection limit $(3 \mathrm{mg} / \mathrm{kg})$. 


\subsection{Environmental Sustainability of the Baganuur Mining Practice}

Scientific data are essential for sustainable development of the mining to decision makers. The results of this study show that availability of water as water resources, and environmental risk of soil including AMD, contaminated leachate, desertification, and the generation of dust. Considering the sedimentary depositional environment of the coal-bearing formations at this study area, the waste soil, similar to S-5, could be extended following the orientation of stratigraphy. Therefore, as a next step to quantify the AMD potential and associated risks to the surrounding environment, a more detailed study should be conducted with the concerted samplings of soil and water for the potential areas. Moreover, organic materials and bacteria (such as T. ferrooxidans), as well as $\mathrm{Fe}^{3+}$, which can accelerate AMD and the release of heavy metals, should be analyzed because inorganic materials were only considered in this study [56]. The leaching test that could accommodate the fractionation of bioavailable phases should also be adopted $[57,58]$. Then, based on the detailed information, the proper or advanced tools for sustainable development and to support decision making could be proposed [59].

\section{Conclusions}

This study was carried out to assess the water and soil pollution potential of the Baganuur Coal Mine, one of the largest open-pit coal mines in Mongolia. Based on its enormous reserves, mining activity at this site is expected to continue for at least several decades; therefore, sustainable mining practices should be developed based on field monitoring data.

Water chemistry show that the sources of major ions, including $\mathrm{Na}, \mathrm{Ca}, \mathrm{Mg}$, and $\mathrm{HCO}_{3}$, include carbonate weathering, dissolution of evaporite minerals, natural softening, and cation exchange processes. $\mathrm{SO}_{4}$ and $\mathrm{NO}_{3}$ could be generated from the dissolution of sulphate minerals such as anhydrite and gypsum, and from mining explosive residue, respectively. Compared with WHO drinking water guidelines and Mongolian water pollution standards, the waters represented by samples DW-1 and -2 appear to be suitable as domestic water resources. Thus, use of groundwater pumped from the mining area as a water supply could benefit local residents, who currently obtain water from the river $13 \mathrm{~km}$ away. In addition, based on SAR analysis, GW-2 and -3 could be used for agriculture water supply with salinity reduction or used to grow halophytes to control desertification, reclaim land, and provide pasture.

The textures of the sampled soils are generally silty loam or sandy loam with primary components of quartz, microcline, and albite. Waste soil that is excavated and removed during the mining process has desertification potentials, as determined through $\mathrm{D}_{\mathrm{m}}$ calculation following PSD analysis. Furthermore, particles forming dust smaller than $150 \mu \mathrm{m}$ comprise more than $80 \%$ of the soils, which have As levels above Mongolian soil pollution standards. The $\mathrm{pH}$ of soil samples ranged from 6.17 to 7.50, except sample S-5, which had a $\mathrm{pH}$ of 2.77 .

S-5 was collected between coal seams and showed relatively high sulphur levels in XRF and SEM-EDX analysis, indicating the potential for AMD and subsequent metal leaching. Analysis of $\mathrm{NAG}_{\mathrm{pH}}$ and NAPP showed that S-5 has potential for acid formation, and metal leaching tests confirmed acid generation, most likely from sulphide minerals based on the negative correlation between $\mathrm{pH}$ and leached $\mathrm{SO}_{4}$. S-5 also showed significant leaching of $\mathrm{Co}$. When the upper coal seam is fully uncovered, then excavation of the second coal seam will start. Before this operation, the sediments of S-5 type should be removed and disposed as waste piles. It is the time the AMD and metal leaching could begin from the waste sediments exposed to the air and rainfall directly at land surface. Therefore, the Baganuur mine should carefully prepare the measures of safe disposal and prevention of environmental pollution.

In summary, water from the Baganuur Coal Mine could be used as a domestic water resource or for agricultural uses to support halophyte pasture crops and thus mitigate the risk of spreading As-containing dust. However, because sulphate and Co could be leached from the waste sediments, local water quality should be regularly monitored. Following the development of the mine, waste soil and discharged water will continue to increase, both in terms of the impacted area and the amount. 
Therefore, continuous efforts, including monitoring and environmental management from both the mining company and the government, are needed to ensure sustainable development.

Author Contributions: J.P. and N.C.W. conceived and designed the research and wrote the paper; J.P., E.K., E.C., and B.B. performed the data collection and analysis; J.P. and H.K. performed XRD and SED-EDX analysis. All authors have read and agreed to the published version of the manuscript.

Funding: This research was supported by the financial support from the National Research Foundation of Korea, projects NRF-2016KIA3A1A08953551 and NRF-2017R1A6A1A07015374.

Acknowledgments: The authors thank Baganuur JSC for their cooperation in the field study at the mine. This paper was published as part of J.P's Master thesis at Yonsei University, 2019.

Conflicts of Interest: The authors declare no conflict of interest.

\section{Appendix A}

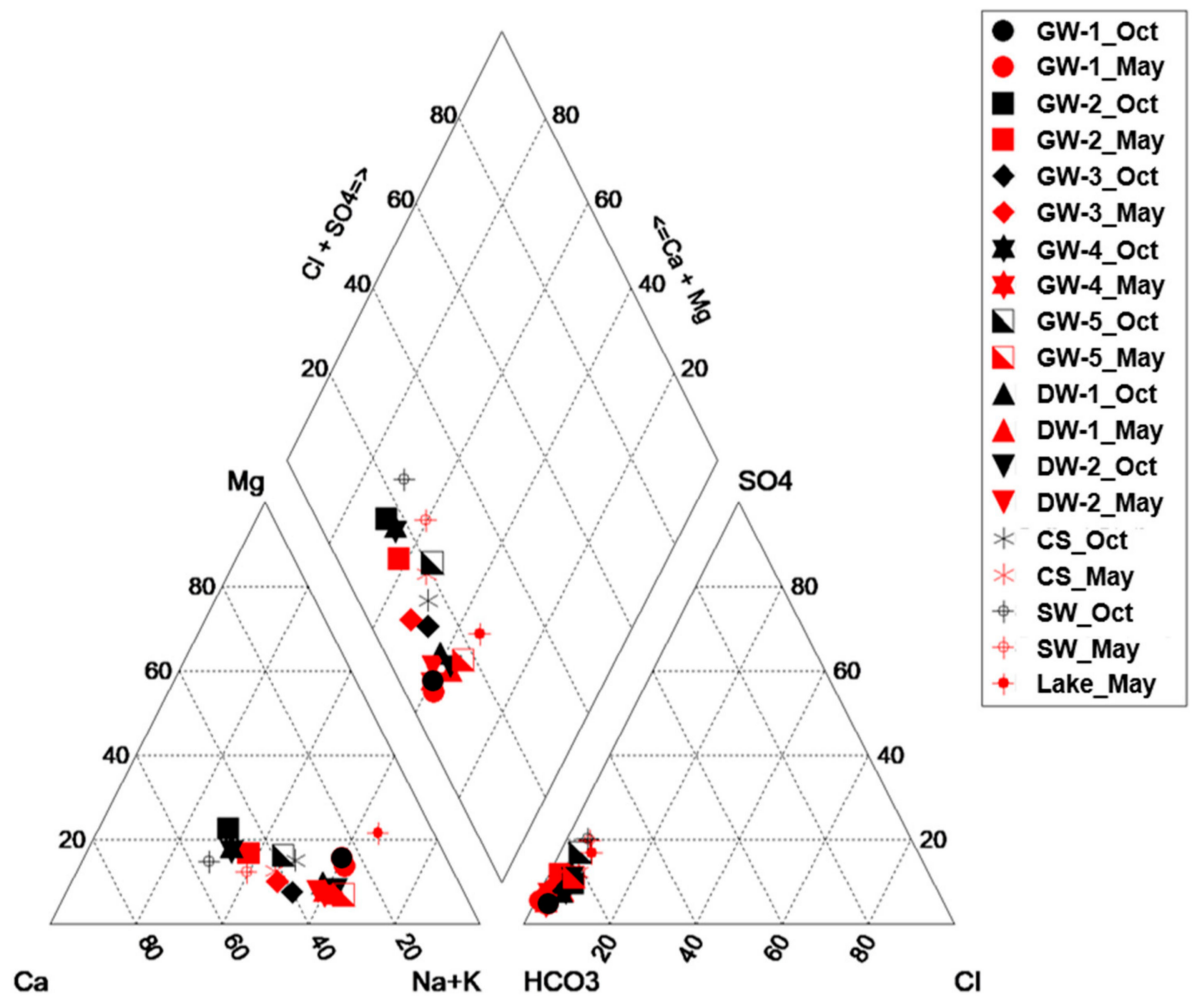

Figure A1. Piper diagram of water samples (GW: Groundwater; DW: Discharge water; CS: Collection station; SW: Sump water).

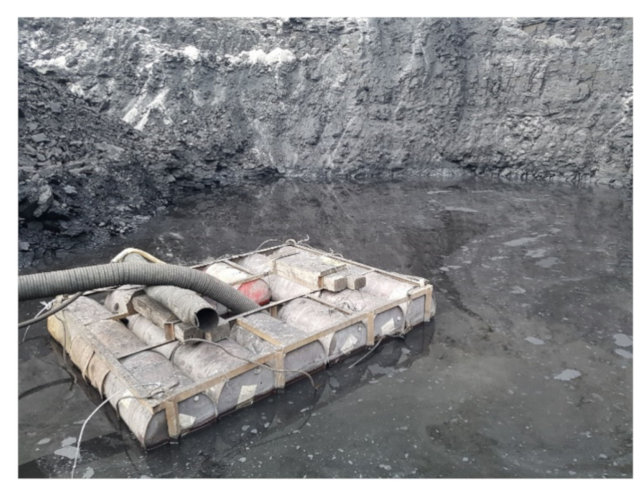

Figure A2. Sampling site for sump water (SW). 


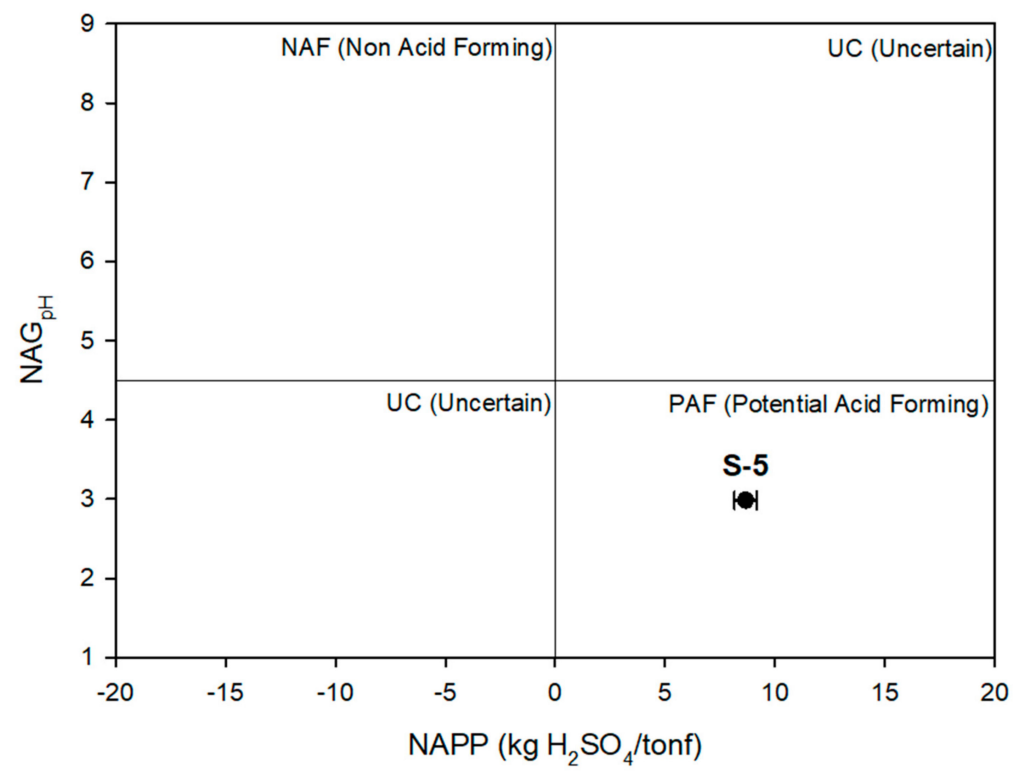

Figure A3. Assessment of the acid generation potential of soil sample S-5 collected between coal seams based on net acid generation $\mathrm{pH}(\mathrm{NAGpH})$ and net acid production potential (NAPP).

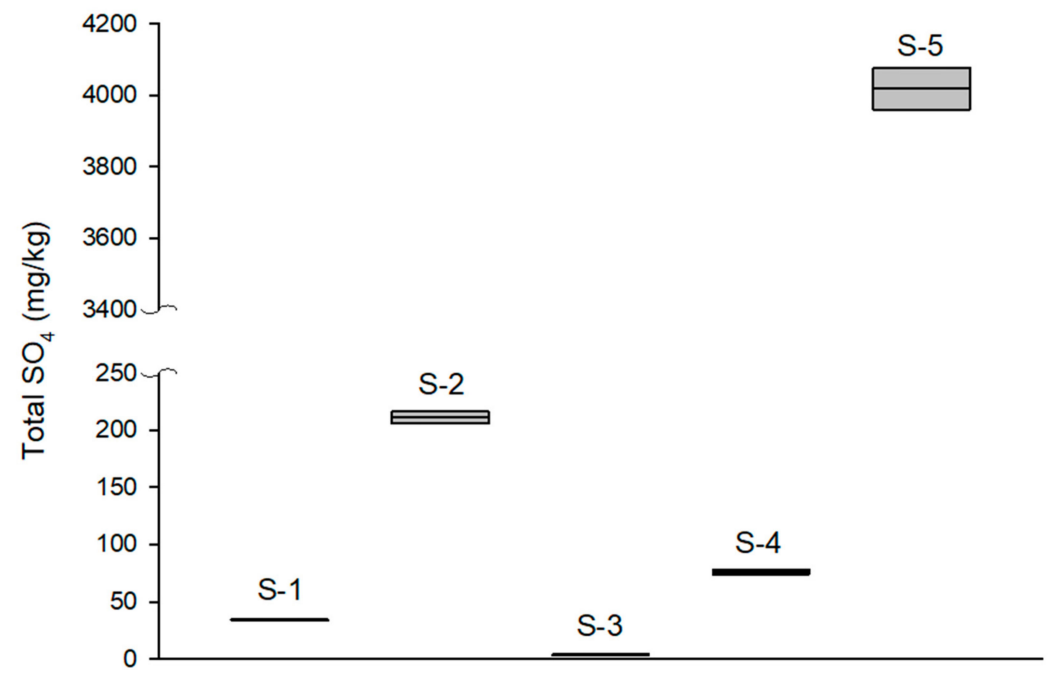

Figure A4. Total $\mathrm{SO}_{4}$ concentration of the leachates.

Table A1. Sampling site of water and soil.

\begin{tabular}{|c|c|c|}
\hline Sample & Latitude & Longitude \\
\hline GW-1 & $\mathrm{N} 47^{\circ} 45^{\prime} 08.3^{\prime \prime}$ & E $108^{\circ} 18^{\prime} 09.8^{\prime \prime}$ \\
\hline GW-2 & $\mathrm{N} 47^{\circ} 44^{\prime} 32.2^{\prime \prime}$ & E $108^{\circ} 18^{\prime} 07.0^{\prime \prime}$ \\
\hline GW-3 & $\mathrm{N} 47^{\circ} 43^{\prime} 18.8^{\prime \prime}$ & E $108^{\circ} 17^{\prime} 50.9^{\prime \prime}$ \\
\hline GW-4 & $\mathrm{N} 47^{\circ} 42^{\prime} 13.4^{\prime \prime}$ & E $108^{\circ} 17^{\prime} 23.5^{\prime \prime}$ \\
\hline GW-5 & $\mathrm{N} 47^{\circ} 41^{\prime} 22.1^{\prime \prime}$ & E $108^{\circ} 16^{\prime} 26.0^{\prime \prime}$ \\
\hline DW-1 & N $47^{\circ} 41^{\prime} 33.7^{\prime \prime}$ & E $108^{\circ} 16^{\prime} 05.3^{\prime \prime}$ \\
\hline DW-2 & $\mathrm{N} 47^{\circ} 43^{\prime} 49.8^{\prime \prime}$ & E $108^{\circ} 18^{\prime} 23.0^{\prime \prime}$ \\
\hline CS & $\mathrm{N} 47^{\circ} 43^{\prime} 06.6^{\prime \prime}$ & E $108^{\circ} 18^{\prime} 13.2^{\prime \prime}$ \\
\hline Lake & $\mathrm{N} 47^{\circ} 41^{\prime} 33.1^{\prime \prime}$ & E $108^{\circ} 16^{\prime} 05.3^{\prime \prime}$ \\
\hline SW & $\mathrm{N} 47^{\circ} 43^{\prime} 49.7^{\prime \prime}$ & E $108^{\circ} 18^{\prime} 23.1^{\prime \prime}$ \\
\hline S-1 & $\mathrm{N} 47^{\circ} 45^{\prime} 21.3^{\prime \prime}$ & E $108^{\circ} 19^{\prime} 04.3^{\prime \prime}$ \\
\hline S-2 & $\mathrm{N} 47^{\circ} 44^{\prime} 25.3^{\prime \prime}$ & E $108^{\circ} 17^{\prime} 41.7^{\prime \prime}$ \\
\hline S-3 & $\mathrm{N} 47^{\circ} 44^{\prime} 15.9^{\prime \prime}$ & E $108^{\circ} 18^{\prime} 04.6^{\prime \prime}$ \\
\hline S-4 & $\mathrm{N} 47^{\circ} 44^{\prime} 25.2^{\prime \prime}$ & E $108^{\circ} 18^{\prime} 44.4^{\prime \prime}$ \\
\hline S-5 & $\mathrm{N} 47^{\circ} 42^{\prime} 45.3^{\prime \prime}$ & E $108^{\circ} 18^{\prime} 18.0^{\prime \prime}$ \\
\hline
\end{tabular}


Table A2. pH, EC, and major ion concentrations of water in October 2017 and May 2018.

\begin{tabular}{|c|c|c|c|c|c|c|c|c|c|c|c|c|c|}
\hline \multirow{2}{*}{ Sample } & & \multirow{2}{*}{$\mathrm{pH}$} & \multirow{2}{*}{$\mathrm{EC}(\mu \mathrm{S} / \mathrm{cm})$} & \multirow{2}{*}{ TDS (mg/L) } & \multicolumn{9}{|c|}{$\mathrm{mg} / \mathrm{L}$} \\
\hline & & & & & $\mathrm{Cl}$ & $\mathrm{HCO}_{3}$ & $\mathrm{NO}_{3}$ & $\mathrm{SO}_{4}$ & $\mathrm{Na}$ & $\mathbf{K}$ & $\mathrm{Ca}$ & $\mathrm{Mg}$ & $\mathrm{SiO}_{2}$ \\
\hline \multirow{2}{*}{ GW-1 } & Oct-2017 & 6.98 & 1703.0 & 1448.7 & 20.11 & 1026.83 & 1.89 & 41.80 & 223.13 & 6.52 & 79.77 & 31.00 & 18.84 \\
\hline & May-2018 & 6.85 & 1548.0 & 1372.3 & 7.36 & 951.55 & BDL & 44.33 & 237.29 & 5.96 & 83.33 & 28.23 & 17.61 \\
\hline \multirow{2}{*}{ GW-2 } & Oct-2017 & 6.63 & 736.5 & 566.3 & 17.73 & 380.23 & 1.99 & 34.13 & 41.01 & 3.00 & 58.11 & 16.86 & 18.53 \\
\hline & May-2018 & 6.93 & 652.2 & 490.3 & 5.37 & 300.50 & BDL & 32.46 & 59.18 & 2.96 & 63.68 & 14.15 & 17.62 \\
\hline \multirow{2}{*}{ GW-3 } & Oct-2017 & 7.29 & 632.4 & 550.2 & 12.75 & 368.03 & BDL & 26.08 & 72.19 & 2.71 & 48.95 & 5.63 & 26.01 \\
\hline & May-2018 & 7.07 & 535.2 & 511.2 & 4.15 & 352.35 & BDL & 24.91 & 59.55 & 2.65 & 46.92 & 6.87 & 25.31 \\
\hline \multirow{2}{*}{ GW-4 } & Oct-2017 & 6.92 & 916.7 & 780.6 & 20.16 & 514.43 & 2.48 & 55.76 & 65.41 & 2.98 & 85.53 & 18.89 & 22.41 \\
\hline & May-2018 & 7.18 & 914.9 & 804.1 & 9.51 & 550.55 & BDL & 23.07 & 132.64 & 3.15 & 63.56 & 8.67 & 22.18 \\
\hline \multirow{2}{*}{ GW-5 } & Oct-2017 & 7.02 & 1103.0 & 915.8 & 19.87 & 577.47 & BDL & 98.66 & 106.92 & 2.96 & 77.30 & 20.36 & 18.70 \\
\hline & May-2018 & 7.24 & 1105.0 & 917.7 & 24.82 & 565.06 & BDL & 59.63 & 176.07 & 2.58 & 67.63 & 10.25 & 15.18 \\
\hline \multirow{2}{*}{ DW-1 } & Oct-2017 & 7.30 & 1164.0 & 1024.9 & 22.29 & 691.33 & BDL & 49.39 & 158.54 & 2.86 & 75.57 & 14.09 & 17.39 \\
\hline & May-2018 & 7.26 & 1145.0 & 1029.6 & 22.68 & 676.18 & BDL & 49.24 & 182.89 & 2.74 & 75.67 & 11.37 & 15.44 \\
\hline \multirow{2}{*}{ DW-2 } & Oct-2017 & 7.48 & 822.4 & 727.0 & 20.43 & 494.10 & BDL & 32.89 & 112.52 & 2.29 & 46.73 & 7.85 & 17.42 \\
\hline & May-2018 & 7.40 & 850.0 & 524.5 & 8.51 & 573.97 & BDL & 35.48 & 122.53 & 2.56 & 62.67 & 8.70 & 17.22 \\
\hline \multirow{2}{*}{ CS } & Oct-2017 & 8.11 & 854.8 & 733.2 & 14.06 & 479.87 & BDL & 53.36 & 92.96 & 4.20 & 59.73 & 15.38 & 23.37 \\
\hline & May-2018 & 8.29 & 801.3 & 677.2 & 19.67 & 416.22 & BDL & 49.46 & 91.20 & 3.34 & 73.03 & 13.51 & 20.08 \\
\hline \multirow{2}{*}{ Lake } & Oct-2017 & 9.16 & 953.1 & ND & ND & ND & ND & ND & ND & ND & ND & ND & ND \\
\hline & May-2018 & 9.02 & 952.7 & 808.3 & 27.54 & 480.48 & BDL & 83.99 & 146.30 & 9.23 & 26.10 & 26.29 & 15.63 \\
\hline \multirow{2}{*}{ SW } & Oct-2017 & 7.04 & 831.8 & 739.8 & 16.46 & 433.10 & 4.11 & 91.88 & 61.29 & 2.91 & 102.62 & 16.69 & 18.09 \\
\hline & Мay-2018 & 7.10 & 847.5 & 724.6 & 17.75 & 420.42 & 9.25 & 87.97 & 78.30 & 3.35 & 84.98 & 13.27 & 17.48 \\
\hline
\end{tabular}

BDL indicates below detection limit $\left(\mathrm{NO}_{3}: 0.5 \mathrm{mg} / \mathrm{L}\right)$. ND indicates not detecting. 
Table A3. Ratios for understanding water-rock interaction.

\begin{tabular}{|c|c|c|c|c|c|c|c|c|c|c|c|c|c|c|}
\hline \multirow{2}{*}{ Sample } & & \multicolumn{7}{|c|}{$\mathrm{meq} / \mathrm{L}$} & \multirow{2}{*}{$\frac{\mathrm{mmol} / \mathrm{L}}{\mathrm{SiO}_{2}}$} & \multicolumn{5}{|c|}{ Ratios } \\
\hline & & $\mathrm{Na}$ & $\mathbf{K}$ & $\mathrm{Ca}$ & Mg & $\mathrm{Cl}$ & $\mathrm{HCO}_{3}$ & $\mathrm{SO}_{4}$ & & $\frac{\mathrm{Na}}{\mathrm{Cl}}$ & $\frac{\mathrm{Ca}}{\mathrm{Ca}+\mathrm{SO}_{4}}$ & $\frac{\mathrm{HCO}_{3}}{\mathrm{SiO}_{2}}$ & $\frac{\mathrm{Mg}}{\mathrm{Ca}+\mathrm{Mg}}$ & $\frac{\mathrm{SiO}_{2}}{\mathrm{Na}+\mathrm{K}-\mathrm{Cl}}$ \\
\hline \multirow{2}{*}{ GW-1 } & Oct-2017 & 9.71 & 0.17 & 3.98 & 2.55 & 0.57 & 16.83 & 0.85 & 0.31 & 17.14 & 0.82 & 53.60 & 0.39 & 0.034 \\
\hline & May-2018 & 10.32 & 0.15 & 4.16 & 2.32 & 0.21 & 15.60 & 0.90 & 0.29 & 49.76 & 0.82 & 53.15 & 0.36 & 0.029 \\
\hline \multirow{2}{*}{ GW-2 } & Oct-2017 & 1.78 & 0.08 & 2.90 & 1.39 & 0.50 & 6.23 & 0.70 & 0.31 & 3.57 & 0.81 & 20.18 & 0.32 & 0.227 \\
\hline & May-2018 & 2.57 & 0.08 & 3.18 & 1.16 & 0.15 & 4.93 & 0.66 & 0.29 & 17.00 & 0.83 & 16.77 & 0.27 & 0.118 \\
\hline \multirow{2}{*}{ GW-3 } & Oct-2017 & 3.14 & 0.07 & 2.44 & 0.46 & 0.36 & 6.03 & 0.53 & 0.43 & 8.74 & 0.82 & 13.92 & 0.16 & 0.152 \\
\hline & May-2018 & 2.59 & 0.07 & 2.34 & 0.57 & 0.12 & 5.78 & 0.51 & 0.42 & 22.16 & 0.82 & 13.69 & 0.19 & 0.166 \\
\hline \multirow{2}{*}{ GW-4 } & Oct-2017 & 2.85 & 0.08 & 4.27 & 1.55 & 0.57 & 8.43 & 1.14 & 0.37 & 5.01 & 0.79 & 22.58 & 0.27 & 0.159 \\
\hline & May-2018 & 5.77 & 0.08 & 3.17 & 0.71 & 0.27 & 9.03 & 0.47 & 0.37 & 21.53 & 0.87 & 24.41 & 0.18 & 0.066 \\
\hline \multirow{2}{*}{ GW-5 } & Oct-2017 & 4.65 & 0.08 & 3.86 & 1.68 & 0.56 & 9.47 & 2.01 & 0.31 & 8.31 & 0.66 & 30.38 & 0.30 & 0.075 \\
\hline & May-2018 & 7.66 & 0.07 & 3.37 & 0.84 & 0.70 & 9.26 & 1.22 & 0.25 & 10.96 & 0.73 & 36.60 & 0.20 & 0.036 \\
\hline \multirow{2}{*}{ DW-1 } & Oct-2017 & 6.90 & 0.07 & 3.77 & 1.16 & 0.63 & 11.33 & 1.01 & 0.29 & 10.99 & 0.79 & 39.11 & 0.24 & 0.046 \\
\hline & May-2018 & 7.96 & 0.07 & 3.78 & 0.94 & 0.64 & 11.08 & 1.00 & 0.26 & 12.45 & 0.79 & 43.08 & 0.20 & 0.035 \\
\hline \multirow{2}{*}{ DW-2 } & Oct-2017 & 4.89 & 0.06 & 2.33 & 0.65 & 0.58 & 8.10 & 0.67 & 0.29 & 8.51 & 0.78 & 27.90 & 0.22 & 0.066 \\
\hline & May-2018 & 5.33 & 0.07 & 3.13 & 0.72 & 0.24 & 9.41 & 0.72 & 0.29 & 22.23 & 0.81 & 32.78 & 0.19 & 0.056 \\
\hline \multirow{2}{*}{ CS } & Oct-2017 & 4.04 & 0.11 & 2.98 & 1.27 & 0.40 & 7.87 & 1.09 & 0.39 & 10.21 & 0.73 & 20.20 & 0.30 & 0.104 \\
\hline & May-2018 & 3.97 & 0.09 & 3.64 & 1.11 & 0.55 & 6.82 & 1.01 & 0.33 & 7.16 & 0.78 & 20.39 & 0.23 & 0.096 \\
\hline \multirow{2}{*}{ Lake } & Oct-2017 & ND & ND & ND & ND & ND & ND & ND & ND & ND & ND & ND & ND & ND \\
\hline & May-2018 & 6.36 & 0.24 & 1.30 & 2.16 & 0.78 & 7.88 & 1.71 & 0.26 & 8.20 & 0.43 & 30.24 & 0.62 & 0.045 \\
\hline \multirow{2}{*}{ SW } & Oct-2017 & 2.67 & 0.07 & 5.12 & 1.37 & 0.46 & 7.10 & 1.88 & 0.30 & 5.75 & 0.73 & 23.55 & 0.21 & 0.132 \\
\hline & May-2018 & 3.41 & 0.09 & 4.24 & 1.09 & 0.50 & 6.89 & 1.80 & 0.29 & 6.81 & 0.70 & 23.66 & 0.20 & 0.097 \\
\hline
\end{tabular}


Table A4. Factor analysis results of water samples in October 2017 and May 2018.

\begin{tabular}{ccccc}
\hline \multirow{2}{*}{ Element } & \multicolumn{2}{c}{ Oct-2017 } & \multicolumn{2}{c}{ May-2018 } \\
\cline { 2 - 5 } & Factor 1 & Factor 2 & Factor 1 & Factor 2 \\
\hline $\mathrm{HCO}_{3}$ & 0.901 & -0.410 & 0.786 & -0.491 \\
$\mathrm{SO}_{4}$ & 0.317 & 0.737 & 0.568 & 0.785 \\
$\mathrm{NO}_{3}$ & 0.318 & 0.724 & 0.233 & 0.730 \\
$\mathrm{Cl}$ & 0.634 & -0.024 & 0.402 & 0.643 \\
$\mathrm{Na}$ & 0.759 & -0.582 & 0.774 & -0.398 \\
$\mathrm{~K}$ & 0.709 & -0.382 & 0.714 & -0.508 \\
$\mathrm{Ca}$ & 0.617 & 0.716 & 0.906 & 0.295 \\
$\mathrm{Mg}$ & 0.893 & 0.081 & 0.793 & -0.395 \\
$\mathrm{SiO}$ & -0.561 & -0.212 & -0.672 & -0.339 \\
Explained variance (\%) & 44.33 & 25.38 & 46.31 & 28.65 \\
Cumulative variance (\%) & 44.33 & 69.71 & 46.31 & 74.96 \\
\hline
\end{tabular}

Table A5. Pearson correlation analysis results of water samples in October 2017.

\begin{tabular}{|c|c|c|c|c|c|c|c|c|c|c|c|}
\hline & $\mathrm{pH}$ & EC & $\mathrm{HCO}_{3}$ & $\mathrm{SO}_{4}$ & $\mathrm{NO}_{3}$ & $\mathrm{Cl}$ & $\mathrm{Na}$ & $\mathbf{K}$ & $\mathrm{Ca}$ & $\mathrm{Mg}$ & $\mathrm{SiO}_{2}$ \\
\hline $\mathrm{pH}$ & 1 & -0.159 & -0.096 & -0.116 & -0.558 & -0.364 & 0.112 & 0.027 & -0.436 & -0.381 & 0.349 \\
\hline EC & & 1 & 0.989 & 0.123 & 0.047 & 0.567 & 0.902 & 0.797 & 0.531 & 0.826 & -0.395 \\
\hline $\mathrm{HCO}_{3}$ & & & 1 & -0.001 & -0.009 & 0.556 & 0.941 & 0.799 & 0.439 & 0.755 & -0.352 \\
\hline $\mathrm{SO}_{4}$ & & & & 1 & 0.322 & 0.133 & -0.156 & -0.093 & 0.627 & 0.332 & -0.293 \\
\hline $\mathrm{NO}_{3}$ & & & & & 1 & 0.008 & -0.265 & 0.145 & 0.593 & 0.414 & -0.213 \\
\hline $\mathrm{Cl}$ & & & & & & 1 & 0.433 & 0.037 & 0.332 & 0.389 & -0.747 \\
\hline $\mathrm{Na}$ & & & & & & & 1 & 0.761 & 0.183 & 0.563 & -0.247 \\
\hline K & & & & & & & & 1 & 0.413 & 0.794 & 0.007 \\
\hline $\mathrm{Ca}$ & & & & & & & & & 1 & 0.800 & -0.138 \\
\hline $\mathrm{Mg}$ & & & & & & & & & & 1 & -0.320 \\
\hline $\mathrm{SiO}_{2}$ & & & & & & & & & & & 1 \\
\hline
\end{tabular}

Table A6. Pearson correlation analysis results of water samples in May 2018.

\begin{tabular}{|c|c|c|c|c|c|c|c|c|c|c|c|}
\hline & $\mathrm{pH}$ & EC & $\mathrm{HCO}_{3}$ & $\mathrm{SO}_{4}$ & $\mathrm{NO}_{3}$ & $\mathrm{Cl}$ & $\mathrm{Na}$ & K & $\mathrm{Ca}$ & $\mathrm{Mg}$ & $\mathrm{SiO}_{2}$ \\
\hline $\mathrm{pH}$ & 1 & -0.216 & -0.239 & 0.090 & -0.140 & 0.451 & -0.197 & -0.251 & 0.031 & -0.243 & 0.067 \\
\hline EC & & 1 & 0.952 & 0.237 & -0.107 & 0.286 & 0.964 & 0.707 & 0.671 & 0.726 & -0.545 \\
\hline $\mathrm{HCO}_{3}$ & & & 1 & 0.038 & -0.216 & 0.097 & 0.956 & 0.695 & 0.512 & 0.658 & -0.385 \\
\hline $\mathrm{SO}_{4}$ & & & & 1 & 0.799 & 0.664 & 0.076 & 0.090 & 0.736 & 0.199 & -0.552 \\
\hline $\mathrm{NO}_{3}$ & & & & & 1 & 0.210 & -0.293 & 0.034 & 0.507 & 0.029 & -0.137 \\
\hline $\mathrm{Cl}$ & & & & & & 1 & 0.293 & -0.240 & 0.475 & -0.123 & -0.573 \\
\hline $\mathrm{Na}$ & & & & & & & 1 & 0.557 & 0.483 & 0.562 & -0.499 \\
\hline K & & & & & & & & 1 & 0.581 & 0.949 & -0.068 \\
\hline $\mathrm{Ca}$ & & & & & & & & & 1 & 0.669 & -0.633 \\
\hline $\mathrm{Mg}$ & & & & & & & & & & 1 & -0.311 \\
\hline $\mathrm{SiO}_{2}$ & & & & & & & & & & & 1 \\
\hline
\end{tabular}


Table A7. Composition of the water samples comparing with WHO drinking water guideline values [37] and Mongolian water pollution standard [36].

\begin{tabular}{|c|c|c|c|c|c|c|c|c|c|c|c|c|c|c|c|c|c|c|c|c|c|c|}
\hline \multirow{2}{*}{\multicolumn{2}{|c|}{ Sample }} & \multirow{2}{*}{$\mathrm{pH}$} & \multicolumn{20}{|c|}{$\mathrm{mg} / \mathrm{L}$} \\
\hline & & & $\mathrm{Na}$ & $\mathrm{K}$ & $\mathrm{Ca}$ & $\mathrm{Mg}$ & $\mathrm{Fe}$ & Mn & $\mathrm{Cu}$ & $\mathrm{Ni}$ & As & $\mathrm{Pb}$ & $\mathrm{Cd}$ & $\mathrm{Cr}$ & $\mathrm{Zn}$ & B & Mo & Co & F & $\mathrm{Cl}$ & $\mathrm{NO}_{3}$ & $\mathrm{SO}_{4}$ \\
\hline \multicolumn{2}{|c|}{$\begin{array}{l}\text { WHO drinking water } \\
\text { guideline values }\end{array}$} & - & - & - & - & - & - & - & 2.00 & 0.07 & 0.01 & 0.01 & 0.003 & 0.05 & - & 2.4 & - & - & 1.5 & - & 50 & - \\
\hline \multicolumn{2}{|c|}{$\begin{array}{l}\text { Mongolian water } \\
\text { pollution standards }\end{array}$} & $6.5-8.5$ & 200 & 8 & 100 & 30 & 0.3 & 0.4 & 0.01 & 0.01 & 0.01 & 0.01 & 0.005 & 0.01 & 0.01 & - & 0.25 & 0.01 & 1.5 & 350 & 50 & 500 \\
\hline \multirow{2}{*}{ GW-1 } & Oct-2017 & 6.98 & 223 & 6.52 & 79.8 & 31.0 & 4.90 & 0.09 & BDL & BDL & BDL & BDL & ND & BDL & BDL & ND & BDL & BDL & 0.75 & 20.11 & 1.89 & 41.80 \\
\hline & May-2018 & 6.85 & 237 & 5.96 & 83.3 & 28.2 & 2.51 & 0.07 & BDL & BDL & $\mathrm{BDL}$ & BDL & ND & BDL & BDL & BDL & BDL & BDL & 0.37 & 7.36 & BDL & 44.33 \\
\hline \multirow{2}{*}{ GW-2 } & Oct-2017 & 6.63 & 41.0 & 3.00 & 58.1 & 16.9 & 2.67 & 0.09 & BDL & BDL & BDL & BDL & ND & BDL & BDL & $\mathrm{ND}$ & BDL & BDL & 0.66 & 17.73 & 1.99 & 34.13 \\
\hline & May-2018 & 6.93 & 59.2 & 2.96 & 63.7 & 14.2 & 2.15 & 0.07 & BDL & BDL & BDL & BDL & ND & BDL & BDL & BDL & BDL & BDL & 0.37 & 5.37 & $\mathrm{BDL}$ & 32.46 \\
\hline \multirow{2}{*}{ GW-3 } & Oct-2017 & 7.29 & 72.2 & 2.71 & 48.9 & 5.63 & 0.48 & 0.08 & BDL & BDL & BDL & BDL & ND & BDL & BDL & $\mathrm{ND}$ & BDL & BDL & 0.50 & 12.75 & BDL & 26.08 \\
\hline & May-2018 & 7.07 & 59.6 & 2.65 & 46.9 & 6.87 & 0.92 & 0.12 & BDL & BDL & BDL & BDL & ND & BDL & $\mathrm{BDL}$ & BDL & $\mathrm{BDL}$ & BDL & 0.30 & 4.15 & BDL & 24.91 \\
\hline \multirow{2}{*}{ GW-4 } & Oct-2017 & 6.92 & 65.4 & 2.98 & 85.5 & 18.9 & 2.00 & 0.26 & BDL & BDL & BDL & BDL & ND & BDL & BDL & $\mathrm{ND}$ & BDL & BDL & 0.64 & 20.16 & 2.48 & 55.76 \\
\hline & May-2018 & 7.18 & 133 & 3.15 & 63.6 & 8.67 & 0.72 & 0.14 & BDL & BDL & BDL & BDL & ND & BDL & BDL & BDL & BDL & BDL & 0.28 & 9.51 & BDL & 23.07 \\
\hline \multirow{2}{*}{ GW-5 } & Oct-2017 & 7.02 & 107 & 2.96 & 77.3 & 20.4 & 1.26 & 0.10 & BDL & BDL & BDL & BDL & ND & BDL & BDL & $\mathrm{ND}$ & BDL & BDL & 0.61 & 19.87 & BDL & 98.66 \\
\hline & May-2018 & 7.24 & 176 & 2.58 & 67.6 & 10.2 & 3.27 & 0.07 & BDL & BDL & BDL & BDL & ND & BDL & BDL & BDL & BDL & BDL & BDL & 24.82 & $\mathrm{BDL}$ & 59.63 \\
\hline \multirow{2}{*}{ DW-1 } & Oct-2017 & 7.30 & 159 & 2.86 & 75.6 & 14.1 & 0.28 & 0.11 & BDL & BDL & BDL & BDL & ND & BDL & BDL & ND & BDL & BDL & 0.55 & 22.29 & BDL & 49.39 \\
\hline & May-2018 & 7.26 & 183 & 2.74 & 75.7 & 11.4 & 0.06 & 0.07 & BDL & BDL & BDL & BDL & ND & BDL & BDL & BDL & BDL & BDL & BDL & 22.68 & BDL & 49.24 \\
\hline \multirow{2}{*}{ DW-2 } & Oct-2017 & 7.48 & 113 & 2.29 & 46.7 & 7.85 & 0.10 & 0.14 & BDL & BDL & BDL & BDL & ND & BDL & BDL & $\mathrm{ND}$ & BDL & BDL & 0.54 & 20.43 & BDL & 32.89 \\
\hline & May-2018 & 7.40 & 123 & 2.56 & 62.7 & 8.70 & 0.05 & 0.16 & BDL & BDL & $\mathrm{BDL}$ & BDL & ND & BDL & BDL & BDL & BDL & BDL & 0.24 & 8.51 & BDL & 35.48 \\
\hline \multirow{2}{*}{ CS } & Oct-2017 & 8.11 & 93.0 & 4.20 & 59.7 & 15.4 & 0.47 & 0.16 & BDL & BDL & BDL & BDL & ND & BDL & BDL & $\mathrm{ND}$ & BDL & BDL & 0.59 & 14.06 & BDL & 53.36 \\
\hline & May-2018 & 8.29 & 91.2 & 3.34 & 73.0 & 13.5 & 0.01 & 0.06 & BDL & BDL & BDL & BDL & ND & BDL & BDL & BDL & BDL & BDL & BDL & 19.67 & BDL & 49.46 \\
\hline \multirow[b]{2}{*}{ Lake } & Oct-2017 & 9.16 & ND & ND & ND & ND & ND & ND & ND & ND & ND & ND & ND & ND & ND & ND & ND & ND & ND & ND & ND & ND \\
\hline & May-2018 & 9.02 & 146 & 9.23 & 26.1 & 26.3 & 0.03 & 0.01 & BDL & BDL & BDL & BDL & ND & BDL & BDL & BDL & BDL & BDL & BDL & 27.54 & BDL & 83.99 \\
\hline \multirow[b]{2}{*}{ SW } & Oct-2017 & 7.04 & 61.3 & 2.91 & 103 & 16.7 & 0.25 & 0.09 & BDL & BDL & BDL & BDL & ND & BDL & BDL & $\mathrm{ND}$ & BDL & BDL & 0.48 & 16.46 & 4.11 & 91.88 \\
\hline & May-2018 & 7.10 & 78.3 & 3.35 & 85.0 & 13.3 & BDL & 0.06 & BDL & BDL & BDL & BDL & ND & BDL & BDL & BDL & BDL & BDL & BDL & 17.75 & 9.25 & 87.97 \\
\hline
\end{tabular}

BDL indicates below detection limit (Cation: $0.01 \mathrm{mg} / \mathrm{L} ; \mathrm{F}: 1.1 \mathrm{mg} / \mathrm{L} ; \mathrm{NO}_{3}: 0.5 \mathrm{mg} / \mathrm{L}$ ). ND indicates not detecting. 
Table A8. PSD, soil texture, fractal dimension $\left(D_{m}\right)$ of soil samples and reference values of $D_{m}$ [49].

\begin{tabular}{|c|c|c|c|c|c|c|c|}
\hline \multirow{2}{*}{ Sample } & \multicolumn{5}{|c|}{ Particle Size Distribution (\%) } & \multirow{2}{*}{$\begin{array}{c}\text { Soil } \\
\text { Texture }\end{array}$} & \multirow{2}{*}{$\begin{array}{c}\text { Fractal } \\
\text { Dimension } \\
\left(D_{m}\right)\end{array}$} \\
\hline & $\begin{array}{c}\text { Clay } \\
(<2 \mu \mathrm{m})\end{array}$ & $\begin{array}{c}\text { Silt } \\
(2-50 \mu \mathrm{m})\end{array}$ & $\begin{array}{l}\text { Fine Sand } \\
(50-250 \mu \mathrm{m})\end{array}$ & $\begin{array}{c}\text { Medium Sand } \\
(250-500 \mu \mathrm{m})\end{array}$ & $\begin{array}{c}\text { Coarse Sand } \\
(500-2000 \mu \mathrm{m})\end{array}$ & & \\
\hline Potential value & & & & & & & $2.555( \pm 0.036)$ \\
\hline Extreme value & & & & & & & $2.298( \pm 0.082)$ \\
\hline S-1 & 2.16 & 44.33 & 43.67 & 4.95 & 4.90 & $\begin{array}{l}\text { Sandy } \\
\text { loam }\end{array}$ & $2.288( \pm 0.040)$ \\
\hline S-2 & 4.51 & 76.16 & 19.33 & 0.00 & 0.00 & Silt loam & $1.978( \pm 0.054)$ \\
\hline S-3 & 6.14 & 64.35 & 28.54 & 0.97 & 0.00 & Silt loam & $2.256( \pm 0.045)$ \\
\hline S-4 & 4.35 & 75.56 & 20.08 & 0.00 & 0.00 & Silt loam & $1.951( \pm 0.053)$ \\
\hline S-5 & 2.06 & 44.79 & 45.34 & 6.46 & 1.34 & $\begin{array}{l}\text { Sandy } \\
\text { loam }\end{array}$ & $2.156( \pm 0.037)$ \\
\hline
\end{tabular}

\section{References}

1. ICMM. Water Management in Mining: A Selection of Case Studies; International Council of Mining and Metals: London, UK, 2012.

2. NSOM. Mongolian Statistical Yearbook; National Statistics Office of Mongolia (NSOM): Ulaanbaatar, Mongolia, 2016.

3. Tiwary, R.K. Environmental impact of coal mining on water regime and its management. Water Air Soil Pollut. 2001, 132, 185-199. [CrossRef]

4. Younger, P.L.; Banwart, S.A.; Hedin, R.S. Mine Water: Hydrology, Pollution, Remediation; Springer Science \& Business Media: Berlin/Heidelberg, Germany, 2002; Volume 5.

5. Zhengfu, B.; Inyang, H.I.; Daniels, J.L.; Frank, O.; Struthers, S. Environmental issues from coal mining and their solutions. Min. Sci. Technol. China 2010, 20, 215-223.

6. Wright, I.A.; Belmer, N.; Davies, P.J. Coal mine water pollution and ecological impairment of one of Australia's most 'protected'high conservation-value rivers. Water AirSoil Pollut. 2017, 228, 90. [CrossRef]

7. Guo, Q.; Yang, Y.; Han, Y.; Li, J.; Wang, X. Assessment of surface-groundwater interactions using hydrochemical and isotopic techniques in a coalmine watershed, NW China. Environ. Earth Sci. 2019, 78, 91. [CrossRef]

8. Candeias, C.; Da Silva, E.F.; Salgueiro, A.R.; Pereira, H.G.; Reis, A.; Patinha, C.; Matos, J.; Ávila, P. Assessment of soil contamination by potentially toxic elements in the Aljustrel mining area in order to implement soil reclamation strategies. Land Degrad. Dev. 2011, 22, 565-585. [CrossRef]

9. Shu, X.-H.; Zhang, Q.; Lu, G.-N.; Yi, X.-Y.; Dang, Z. Pollution characteristics and assessment of sulfide tailings from the Dabaoshan Mine, China. Int. Biodeterior. Biodegrad. 2018, 128, 122-128. [CrossRef]

10. Evangelou, V. Pyrite Oxidation and Its Control; CRC Press: Boca Raton, FL, USA, 2018.

11. Faure, G. Principles and Applications of Geochemistry; Prentice Hall: Upper Saddle River, NJ, USA, 1997; Volume 625.

12. Kefeni, K.K.; Msagati, T.A.; Mamba, B.B. Acid mine drainage: Prevention, treatment options, and resource recovery: A review. J. Clean. Prod. 2017, 151, 475-493. [CrossRef]

13. Li, X.; Hiroyoshi, N.; Tabelin, C.B.; Naruwa, K.; Harada, C.; Ito, M. Suppressive effects of ferric-catecholate complexes on pyrite oxidation. Chemosphere 2019, 214, 70-78. [CrossRef] [PubMed]

14. Carbone, C.; Dinelli, E.; Marescotti, P.; Gasparotto, G.; Lucchetti, G. The role of AMD secondary minerals in controlling environmental pollution: Indications from bulk leaching tests. J. Geochem. Explor. 2013, 132, 188-200. [CrossRef]

15. Plaza, F.; Wen, Y.; Perone, H.; Xu, Y.; Liang, X. Acid rock drainage passive remediation: Potential use of alkaline clay, optimal mixing ratio and long-term impacts. Sci. Total Environ. 2017, 576, 572-585. [CrossRef]

16. Riera, J.; Cánovas, C.R.; Olías, M. Characterization of main AMD inputs to the Odiel River upper reach (SW Spain). Procedia Earth Planet. Sci. 2017, 17, 602-605. [CrossRef]

17. Blacksmith Institute and Green Cross. The World's Worst Pollution Problems: Assessing Health Risks at Hazardous Waste Sites; Blacksmith Institute: New York, NY, USA; Green Cross: Geneva, Switzerland, 2012.

18. MOE; Baganuur JSC. Baganuur Coal Mine Expansion Feasibility Study; Ministry of Energy (MOE); Baganuur JSC: Baganuur, Mongolia, 2016. 
19. Erdenetsogt, B.-O.; Lee, I.; Bat-Erdene, D.; Jargal, L. Mongolian coal-bearing basins: Geological settings, coal characteristics, distribution, and resources. Int. J. Coal Geol. 2009, 80, 87-104. [CrossRef]

20. Dill, H.; Altangerel, S.; Bulgamaa, J.; Hongor, O.; Khishigsuren, S.; Majigsuren, Y.; Myagmarsuren, S.; Heunisch, C. The Baganuur coal deposit, Mongolia: Depositional environments and paleoecology of a Lower Cretaceous coal-bearing intermontane basin in Eastern Asia. Int. J. Coal Geol. 2004, 60, 197-236. [CrossRef]

21. Komnitsas, K.; Modis, K. Soil risk assessment of As and $\mathrm{Zn}$ contamination in a coal mining region using geostatistics. Sci. Total Environ. 2006, 371, 190-196. [CrossRef]

22. Berg, E.L. Handbook for Sampling and Sample Preservation of Water and Wastewater; ARMSTRONG LAB BROOKS AFB TX: Washington DC, USA, 1992.

23. Weight, W.D. Hydrogeology Field Manual; McGraw-Hill: New York, NY, USA, 2008.

24. EPA. Soil Sampling Operating Procedure; Science and Ecosystem Support Division, Environmental Protection Agency: Athens, GA, USA, 2007.

25. Hounslow, A. Water Quality Data: Analysis and Interpretation; CRC Press: Boca Raton, FL, USA, 2018.

26. Xenco Laboratories. Method 3050B Acid Digestion of Sediments, Sludges, and Soils 1.0 Scope and Application. Available online: http://xenco.com/mobile/pdf/tech/SW846/SW846-3000series/SW846-3050b.pdf (accessed on 26 December 2019).

27. ASTM International. D6357-11 Test Methods for Determination of Trace Elements in Coal, Coke, E Combustion Residues from Coal Utilization Processes by Inductively Coupled Plasma Atomic Emission, Inductively Coupled Plasma Mass, E Graphite Furnace Atomic Absorption Spectrometry; ASTM International: West Conshohocken, PA, USA, 2011.

28. Kim, A.G. Leaching Methods Applied to the Characterization Of Coal Utilization By-Products; Regulation, Risk, and Reclamation With Coal Combustion By-Products at Mines: A Technical Interactive Forum; Citeseer: State College, PA, USA, 2005; p. 89.

29. ASTM International. D4793-09(2017) Standard Test Method for Sequential Batch Extraction of Waste with Water; ASTM International: West Conshohocken, PA, USA, 2017.

30. Jin, Z.; Dong, Y.; Qi, Y.; Liu, W.; An, Z. Characterizing variations in soil particle-size distribution along a grass-desert shrub transition in the ordos plateau of Inner Mongolia, China. Land Degrad. Dev. 2013, 24, 141-146. [CrossRef]

31. Gui, D.; Lei, J.; Zeng, F.; Mu, G.; Zhu, J.; Wang, H.; Zhang, Q. Characterizing variations in soil particle size distribution in oasis farmlands-A case study of the Cele Oasis. Math. Comput. Model. 2010, 51, 1306-1311. [CrossRef]

32. Battogtokh, B.; Woo, N.; Nemer, B. Environmental reconnaissance of the Shivee-Ovoo coalmine area, Mongolia. Environ. Earth Sci. 2012, 67, 1927-1938. [CrossRef]

33. Freeze, R.A.; Cherry, J.A. Groundwater; Prentice Hall: Upper Saddle River, NJ, USA, 1979.

34. Warren, J.K. Evaporites: Sediments, Resources and Hydrocarbons; Springer Science \& Business Media: Berlin/Heidelberg, Germany, 2006.

35. Forsyth, B.; Cameron, A.; Miller, S. Explosives and Water Quality; Golder Associates Ltd.: Sudbury, ON, Canada, 1995; pp. 795-803.

36. MNCSM. MNS 4586: Water Quality Standard; Mongolian National Center of Standardization and Metrology (MNCSM): Ulaanbaatar, Mongolia, 1998.

37. Edition, F. Guidelines For Drinking-Water Quality; WHO Chronicle: Geneva, Switzerland, 2011; Volume 38, pp. 104-108.

38. Bernstein, L. Effects of salinity and sodicity on plant growth. Annu. Rev. phytopathol. 1975, 13, $295-312$. [CrossRef]

39. Richards, L. Diagnosis and Improvement of Saline and Alkali Soils; Handbook No. 60; US Department of Agriculture: Washington, DC, USA, 1954.

40. Wilcox, L. Classification and Use of Irrigation Waters; US Department of Agriculture: Washington, DC, USA, 1955; Volume 969.

41. Le Houérou, H. Forage halophytes and salt-tolerant fodder crops in the Mediterranean Basin. In Halophytes as a Resource for Livestock and for Rehabilitation of Degraded Lands; Springer: Berlin/Heidelberg, Germany, 1994; pp. 123-137.

42. El Shaer, H.M. Potential of halophytes as animal fodder in Egypt. In Cash Crop Halophytes: Recent Studies; Springer: Berlin/Heidelberg, Germany, 2003; pp. 111-119. 
43. Al-Farrajii, F.; Al-Hilli, M. Halophytes and desertification control in Iraq. In Halophytes as a Resource for Livestock and for Rehabilitation of Degraded Lands; Springer: Berlin/Heidelberg, Germany, 1994; pp. 239-248.

44. Romero-Baena, A.J.; González, I.; Galán, E. Soil pollution by mining activities in Andalusia (South Spain)—the role of Mineralogy and Geochemistry in three case studies. J. Soils Sediments 2018, 18, 2231-2247. [CrossRef]

45. Sobek, A.A. Field and Laboratory Methods Applicable to Overburdens and Minesoils; Industrial Environmental Research Laboratory, Office of Research and Development, US Environmental Protection Agency: Cincinnati, OH, USA, 1978.

46. Skousen, J.; Simmons, J.; McDonald, L.; Ziemkiewicz, P. Acid-base accounting to predict post-mining drainage quality on surface mines. J. Environ. Qual. 2002, 31, 2034-2044. [CrossRef]

47. Yun, H.-S.; Gee, E.D.; Ji, M.K.; Lee, W.R.; Yang, J.-S.; Park, Y.-T.; Kwon, H.-h.; Ji, W.-H.; Kim, K.; Jeon, B.-H. Developing for reduction technology of AMD through coating on the surface of pyrite using minerals. J. Korean Geoenviron. Soc. 2011, 12, 15-22.

48. Modabberi, S.; Alizadegan, A.; Mirnejad, H.; Esmaeilzadeh, E. Prediction of AMD generation potential in mining waste piles, in the sarcheshmeh porphyry copper deposit, Iran. Environ. Monit. Assess. 2013, 185, 9077-9087. [CrossRef]

49. Su, Y.Z.; Zhao, H.L.; Zhao, W.Z.; Zhang, T.H. Fractal features of soil particle size distribution and the implication for indicating desertification. Geoderma 2004, 122, 43-49. [CrossRef]

50. World Health Organization. Hazard Prevention and Control in the Work Environment: Airborne Dust; No. WHO/SDE/OEH/99.14; World Health Organization: Geneva, Switzerland, 1999.

51. Sapko, M.J.; Cashdollar, K.L.; Green, G.M. Coal dust particle size survey of US mines. J. Loss Prev. Process Ind. 2007, 20, 616-620. [CrossRef]

52. Perret, J.L.; Plush, B.; Lachapelle, P.; Hinks, T.S.C.; Walter, C.; Clarke, P.; Irving, L.; Brady, P.; Dharmage, S.C.; Stewart, A. Coal mine dust lung disease in the modern era. Respirology 2017, 22, 662-670. [CrossRef] [PubMed]

53. Farzan, S.F.; Karagas, M.R.; Chen, Y. In utero and early life arsenic exposure in relation to long-term health and disease. Toxicol. Appl. Pharm. 2013, 272, 384-390. [CrossRef] [PubMed]

54. Quansah, R.; Armah, F.A.; Essumang, D.K.; Luginaah, I.; Clarke, E.; Marfoh, K.; Cobbina, S.J.; Nketiah-Amponsah, E.; Namujju, P.B.; Obiri, S.; et al. Association of Arsenic with Adverse Pregnancy Outcomes/Infant Mortality: A Systematic Review and Meta-Analysis. Environ. Health Perspect. 2015, 123, 412-421. [CrossRef] [PubMed]

55. MNCSM. MSN 5850: Soil Quality. Soil Pollutants Elements and Substance; Mongolian National Center of Standardization and Metrology (MNCSM): Ulaanbaatar, Mongolia, 2008.

56. Komnitsas, K.; Xenidis, A.; Adam, K. Oxidation of pyrite and arsenopyrite in sulphidic spoils in Lavrion. Miner. Eng. 1995, 8, 1443-1454. [CrossRef]

57. Kamenopoulos, S.; Agioutantis, Z.; Komnitsas, K. A new hybrid decision support tool for evaluating the sustainability of mining projects. Int. J. Min. Sci. Technol. 2018, 28, 259-265. [CrossRef]

58. Filgueiras, A.V.; Lavilla, I.; Bendicho, C. Chemical sequential extraction for metal partitioning in environmental solid samples. J. Environ. Monit. 2002, 4, 823-857. [CrossRef]

59. Kontopoulos, A.; Komnitsas, K.; Xenidis, A.; Papassiopi, N. Environmental characterization of the sulphidic tailings in lavrion. Miner. Eng. 1995, 8, 1209-1219. [CrossRef]

(C) 2019 by the authors. Licensee MDPI, Basel, Switzerland. This article is an open access article distributed under the terms and conditions of the Creative Commons Attribution (CC BY) license (http://creativecommons.org/licenses/by/4.0/). 